\title{
TANK 4 CHARACTERIZATION, SETTLING, AND WASHING STUDIES
}

\author{
C. J. Bannochie \\ J. M. Pareizs \\ D. R. Click \\ J. R. Zamecnik
}

September 2009

Savannah River National Laboratory Savannah River Nuclear Solutions Aiken, SC 29808

Prepared for the U.S. Department of Energy Under Contract Number DE-AC09-08SR22470

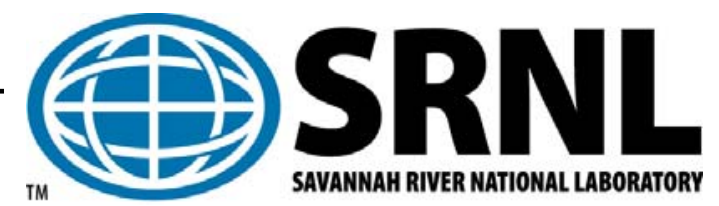


SRNL-STI-2009-00544

Revision 0

\section{DISCLAIMER}

This work was prepared under an agreement with and funded by the U.S. Government. Neither the U. S. Government or its employees, nor any of its contractors, subcontractors or their employees, makes any express or implied:

1. warranty or assumes any legal liability for the accuracy, completeness, or for the use or results of such use of any information, product, or process disclosed; or

2. representation that such use or results of such use would not infringe privately owned rights; or

3. endorsement or recommendation of any specifically identified commercial product, process, or service.

Any views and opinions of authors expressed in this work do not necessarily state or reflect those of the United States Government, or its contractors, or subcontractors.

Printed in the United States of America

Prepared For

U.S. Department of Energy 
Key Words: DWPF, SB6, Tank 4

Retention: PERMANENT

\section{TANK 4 CHARACTERIZATION, SETTLING, AND WASHING STUDIES}

C. J. Bannochie

J. M. Pareizs

D. R. Click

J. R. Zamecnik

September 2009

Savannah River National Laboratory

Savannah River Nuclear Solutions

Aiken, SC 29808

Prepared for the U.S. Department of Energy Under

Contract Number DE-AC09-08SR22470

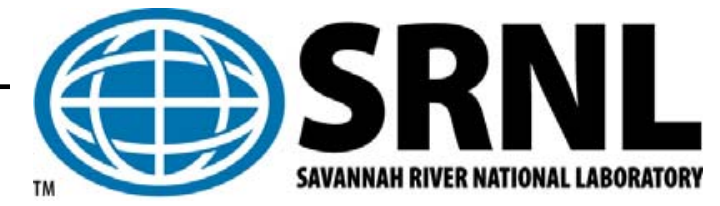




\section{REVIEWS AND APPROVALS}

\section{AUTHOR(S):}

C. J. Bannochie, Process Technology Programs

Date

J. M. Pareizs, Process Technology Programs

Date

D. R. Click, Analytical Development

Date

J. R. Zamecnik, Engineering Process Development

Date

\section{TECHNICAL REVIEWERS:}

S. H. Reboul, Process Technology Programs

Date

N. E. Bibler, Process Technology Programs

Date

\section{APPROVERS}

C. C. Herman, Manager, Process Technology Programs

Date

S. L. Marra, Manager, Research Programs, E\&CPT

Date

D. C. Bumgardner, Tank Farm Engineering

Date 


\section{EXECUTIVE SUMMARY}

A sample of PUREX sludge from Tank 4 was characterized, and subsequently combined with a Tank 51 sample (Tank 51-E1) received following Al dissolution, but prior to a supernate decant by the Tank Farm, to perform a settling and washing study to support Sludge Batch 6 preparation. The sludge source for the majority of the Tank 51-E1 sample is Tank $12 \mathrm{HM}$ sludge. The Tank 51-E1 sample was decanted by SRNL prior to use in the settling and washing study. The Tank 4 sample was analyzed for chemical composition including noble metals. The characterization of the Tank 51-E1 sample, used here in combination with the Tank 4 sample, was reported previously ${ }^{1}$.

SRNL analyses on Tank 4 were requested by Liquid Waste Engineering (LWE) via Technical Task Request (TTR) HLE-TTR-2009-1032. The sample preparation work is governed by Task Technical and Quality Assurance Plan (TTQAP) ${ }^{3}$, and analyses were controlled by an Analytical Study Plan ${ }^{4}$ and modifications received via customer communications. Additional scope included a request for a settling study of decanted Tank 51-E1 and a blend of decanted Tank 51-E1 and Tank 4, as well as a washing study to look into the fate of undissolved sulfur observed during the Tank 4 characterization. The chemistry of the Tank 4 sample was modeled with OLI Systems, Inc. StreamAnalyzer to determine the likelihood that sulfate could exist in this sample as insoluble Burkeite $\left(2 \mathrm{Na}_{2} \mathrm{SO}_{4} \cdot \mathrm{Na}_{2} \mathrm{CO}_{3}\right)$. The OLI model was also used to predict the composition of the blended tank materials for the washing study.

The following conclusions were drawn from the Tank 4 analytical results reported here:

- Any projected blend of Tank 4 and the current Tank 51 contents will produce a SB6 composition that is lower in $\mathrm{Ca}$ and $\mathrm{U}$ than the current SB5 composition being processed by DWPF.

- Unwashed Tank 4 has a relatively large initial $\mathrm{S}$ concentration of $3.68 \mathrm{wt} \%$ on a total solids basis, and approximately $10 \%$ of the total $\mathrm{S}$ is present as an insoluble or undissolved form.

- There is $19 \%$ more $\mathrm{S}$ than can be accounted for by IC sulfate measurement. This additional soluble $\mathrm{S}$ is detected by ICP-AES analysis of the supernate.

- Total supernate and slurry sulfur by ICP-AES should be monitored during washing in addition to supernate sulfate in order to avoid under estimating the amount of sulfur species removed or remaining in the supernate.

- OLI simulation calculations show that the presence of undissolved Burkeite in the Tank 4 sample is reasonable, assuming a small difference in the Na concentration that is well within the analytical uncertainties of the reported value.

The following conclusions were drawn from the blend studies of Tank 4 and decanted Tank 51-E1:

- The addition of Tank 4 slurry to a decanted Tank 51-E1 sample significantly improved the degree and time for settling.

- The addition of Tank 4 slurry to a decanted Tank 51-E1 sample significantly improved the plastic viscosity and yield stress.

- The SRNL washing test, where nearly all of the wash solution was decanted from the solids, indicates that approximately $96 \%$ or more of the total $\mathrm{S}$ was removed from the blend in these tests, and the removal of the sulfur tracks closely with that of $\mathrm{Na}$. Insoluble (undissolved) $\mathrm{S}$ 
remaining in the washed sludge was calculated from an estimate of the final slurry liquid fraction, the $\mathrm{S}$ result in the slurry digestion, and the $\mathrm{S}$ in the final decant (which was very close to the method detection limit). Based on this calculated result, about $4 \%$ of the initial total $\mathrm{S}$ remained after these washes; this amount is equivalent to about $18 \%$ of the initially undissolved $\mathrm{S}$.

${ }^{1}$ Pickenheim, B. R., Bannochie, C. J., Pareizs, J. M., and Click, D. R. Results of the Analysis of Tank 51 E-1 Sample (HTF-51-09-74 \& -75) and Tank 12 Post-Aluminum Dissolution Rheology, SRNL-L3100-2009-00190, Savannah River Site, Aiken, SC 29808 (2009).

${ }^{2}$ Martin, K. B. Tank 4F Characterization in Support of Bulk Waste Removal and Sludge Batch Preparation, HLETTR-2009-103, Rev. 0, Savannah River Site, Aiken, SC 29808 (2009).

${ }^{3}$ Bannochie, C. J., Pareizs, J. M. Qualification of DWPF Sludge Batch 6 and Characterization of Tank 4 Samples in the SRNL Shielded Cells: Task Technical and Quality Assurance Plan, SRNL-RP-2009-00473, Rev. 0, Savannah River Site, Aiken, SC 29808 (2009).

${ }^{4}$ Bannochie, C. J., Pareizs, J. M. Qualification of DWPF Sludge Batch 6 and Characterization of Tank 4 in the SRNL Shielded Cells: Analytical Study Plan, SRNL-RP-2009-00474, Rev. 0, Savannah River Site, Aiken, SC 29808 (2009). 
TABLE OF CONTENTS

EXECUTIVE SUMMARY iv

LIST OF FIGURES vii

LIST OF TABLES

viii

LIST OF ACRONYMS/Abbreviations

ix

1.0 INTRODUCTION AND BACKGROUND

2.0 APPROACH AND RESULTS

2.1 Analytical Methods

2.2 Analytical Results

2.3 Rheology Methods

2.4 Rheology Results

2.5 Settling Study Methods

2.6 Settling Study Results

2.7 Modeling Study Methods

2.8 Modeling Study Results

2.9 Washing Study Methods

2.10 Washing Study Results

3.0 DISCUSSION

3.1 Sulfur

3.2 Elemental Ratios

3.3 Noble Metal Ratios

3.4 Rheology Conclusions

3.5 Settling Study Observations

3.6 Modeling Observations

3.7 Sludge Washing

4.0 CONCLUSIONS

25

5.0 REFERENCES 


\section{LIST OF FIGURES}

Figure 2-1. Tank 4 Shear Stress vs. Shear Rate Replicate 1 .............................................. 8

Figure 2-2. Tank 4 Shear Stress vs. Shear Rate Replicate 2 .............................................. 9

Figure 2-3. Decanted Tank 51-E1 (43\% of total volume removed) Shear Stress vs. Shear Rate Replicate 1

Figure 2-4. Decanted Tank 51-E1 (43\% of total volume removed) Shear Stress vs. Shear Rate Replicate 2

Figure 2-5. Tank 4/Decanted Tank 51-E1 Blend Shear Stress vs. Shear Rate Replicate 1 ......... 10

Figure 2-6. Tank 4/Decanted Tank 51-E1 Blend Shear Stress vs. Shear Rate Replicate 2 ......... 11

Figure 2-7. Comparison of settled volume (mL) vs. time (days) for a decanted Tank 51-E1 sample and a blend of Tank 51-E1 and Tank 4. 


\section{LIST OF TABLES}

Table 2-1. Weight Percent Solids and Density for Tank 4 Samples [Number of Samples Included in Average]

Table 2-2. Supernate Analyses for Tank 4 Samples [Number of Samples Included in Average]. 5

Table 2-3. Base Analysis for Tank 4 Samples [Number of Samples Included in Average].......... 5

Table 2-4. Elemental Concentrations* in Tank 4 Samples in Wt \% of Total Solids (\%RSD) [Number of Samples Included in Average] .......................................................... 6

Table 2-5. Noble Metal Fission Products and Silver Concentrations in Tank 4 in Wt \% of Total Solids (\%RSD)

Table 2-6. MV I Rotor Specifications and Flow Curve Program

Table 2-7. Rheology Summary for Tank 4, Decanted Tank 51-E1, and Tank 4/Decanted Tank 51-E1 Blend.

Table 2-8. Input Concentrations for OLI StreamAnalyzer Model of Tank 4 Slurry .................. 13

Table 2-9. Input Parameters for OLI StreamAnalyzer Model of Tank 4 Slurry........................ 14

Table 2-10. Predicted Tank 4 Composition .............................................................................. 15

Table 2-11. Predicted Tank 4 Properties................................................................................ 15

Table 2-12. Sulfate Washing Slurry Masses, Decant Masses, and Wash Water Masses ........... 16

Table 2-13. Major Elements (>1,000 mg/kg), Nitrite and Nitrate in the Decanted-Tank 51/Tank 4 Blend Prior to Washing Calculated by OLI From Analyses for Tank 51 and Tank 4.

Table 2-14. Analytical Results for the Decants from Washing the Decanted-Tank 51/Tank 4 Sludge Blend

Table 2-15. Major Elements $(>1,000 \mathrm{mg} / \mathrm{kg})$ Detected by ICP-AES in the Washed DecantedTank 51/Tank 4 Sludge Blend

Table 3-1. Comparison of Elemental Ratios for Major Elements in the Tank 4, Tank 51-E1, and Current SB5 Samples.

Table 3-2. Fission Yield Ratios and Measured Noble Metal Ratios for Tank 4, Tank 51-E1, and the SB5 WAPS Samples....

Table 3-3. Mass Balance for Washing the Decanted-Tank 51/Tank 4 Sludge Blend ................ 22

Table 3-4. Cumulative Component Percent Removed Following Each Decant......................... 23

Table 3-5. Calculations of Insoluble $\mathrm{Na}$ and $\mathrm{S}$ in Washed Slurry with Comparison to Initial Amounts 


\section{LIST OF ACRONYMS/ABBREVIATIONS}

\begin{tabular}{ll} 
AD & Analytical Development \\
ARG -1 & Analytical Reference Glass - 1 \\
ASP & Analytical Study Plan \\
CV-AA & Cold Vapor - Atomic Absorption Spectroscopy \\
DWPF & Defense Waste Processing Facility \\
IC & Ion Chromatography \\
ICP-AES & Inductively Coupled Plasma - Atomic Emission Spectroscopy \\
ICP-MS & Inductively Coupled Plasma - Mass Spectrometry \\
HM & H-Area Modified PUREX \\
L & Liter \\
LWE & Liquid Waste Engineering \\
M & Molar \\
NA & Not Available (e.g. Not Measured) \\
NIST & National Institute of Standards and Testing \\
PUREX & Plutonium Uranium Redox Extraction \\
RSD & Relative Standard Deviation \\
SB5 & Sludge Batch 5 \\
SB6 & Sludge Batch 6 \\
SME & Slurry Mix Evaporator \\
SRNL & Savannah River National Laboratory \\
SRS & Savannah River Site \\
Std. Dev. & Standard Deviation \\
TS & Total Solids \\
TTR & Technical Task Request \\
WAPS & Waste Acceptance Product Specifications \\
Wt \% & Weight Percent \\
& \\
\hline &
\end{tabular}




\subsection{INTRODUCTION AND BACKGROUND}

A sample of PUREX sludge from Tank 4 was characterized, and subsequently combined with a Tank 51 sample (Tank 51-E1) received following Al dissolution, but prior to a supernate decant by the Tank Farm, to perform a settling and washing study to support Sludge Batch 6 (SB6) preparation. The sludge source for the majority of the Tank 51-E1 sample is Tank 12 HM sludge. The Tank 51-E1 sample was decanted by SRNL prior to use in the settling and washing study. The Tank 4 sample was analyzed for chemical composition including noble metals. The characterization of the Tank 51-E1 sample, used here in combination with the Tank 4 sample, was reported previously ${ }^{1}$.

SRNL analyses on Tank 4 were requested by Liquid Waste Engineering (LWE) via Technical Task Request (TTR) HLE-TTR-2009-1032. The sample preparation work is governed by a Task Technical and Quality Assurance Plan (TTQAP) ${ }^{3}$, and analyses were controlled by an Analytical Study Plan $^{4}$ and modifications received via customer communications. Additional scope included a request for a settling study of decanted Tank 51-E1 and a blend of decanted Tank 51-E1 and Tank 4, as well as a washing study to look into the fate of undissolved sulfur observed during the Tank 4 characterization. The chemistry of the Tank 4 sample was modeled with OLI Systems, Inc. StreamAnalyzer to determine the likelihood that sulfate could exist in this sample as insoluble Burkeite $\left(2 \mathrm{Na}_{2} \mathrm{SO}_{4} \cdot \mathrm{Na}_{2} \mathrm{CO}_{3}\right)$. The OLI model was also used to predict the composition of the blended tank materials for the washing study.

One 1-L sample of Tank 4 was pulled on July 20, 2009 following slurry operations. The sample was designated FTF-04-09-32 by F-Tank Farm Operations. The sample was sent to SRNL on July 21, 2009. 
SRNL-STI-2009-00544

Revision 0

This page intentionally left blank. 


\subsection{APPROACH AND RESULTS}

\subsection{Analytical Methods}

At the Savannah River National Laboratory (SRNL), the 1-L Tank 4 sample was transferred from the shipping container into a 2-L high density polyethylene bottle and solids allowed to settle overnight. Supernate was then siphoned off and circulated through the shipping container to complete the transfer of the sample of $1598 \mathrm{~g}$. Following thorough mixing of the 1-L sample, a $233 \mathrm{~g}$ sub-sample was removed. This sub-sample was then utilized for all subsequent analytical samples.

Eight separate aliquots of the slurry were digested, four with $\mathrm{HNO}_{3} / \mathrm{HCl}$ (aqua regia ${ }^{5}$ ) in sealed Teflon ${ }^{\circledR}$ vessels and four in $\mathrm{Na}_{2} \mathrm{O}_{2}$ (alkali or peroxide fusion ${ }^{6}$ ) using $\mathrm{Zr}$ crucibles. Due to the use of $\mathrm{Zr}$ crucibles and $\mathrm{Na}$ in the peroxide fusions, $\mathrm{Na}$ and $\mathrm{Zr}$ cannot be determined from this preparation. Additionally, other alkali metals, such as $\mathrm{Li}$ and $\mathrm{K}$ that may be contaminants in the $\mathrm{Na}_{2} \mathrm{O}_{2}$ are not determined from this preparation. Three Analytical Reference Glass $-1^{7}$ (ARG-1) standards were digested along with a blank for each preparation. The ARG-1 glass allows for an assessment of the completeness of each digestion. Each aqua regia digestion and blank was diluted to $1: 100 \mathrm{~mL}$ with deionized water and submitted to Analytical Development (AD) for inductively coupled plasma - atomic emission spectroscopy (ICPAES) analysis, inductively coupled plasma - mass spectrometry (ICP-MS) analysis of masses 81-209 and 230-252, and cold vapor atomic absorption (CV-AA) analysis for Hg. Equivalent dilutions of the peroxide fusion digestions and blank were submitted to AD for ICP-AES analysis.

Tank 4 supernate was collected with a $0.45 \mu \mathrm{m}$ filter cup from a mixed slurry sample in the SRNL Shielded Cells and submitted to AD for ICP-AES, ion chromatography (IC), and total base analyses.

\subsection{Analytical Results}

Table 2-1 presents the measured Tank 4 density and weight percent solids data ${ }^{8}$. A calcine factor was also calculated by taking the ratio of the weight percent calcined solids and the weight percent total solids. The Tank 4 Sample has a value of 0.60 grams of calcined solids per gram of dried solids. Due to the high dissolved solids a new technique was employed to measure the calcine value. A known amount of frit was added to the dried total solids, and the mixture calcined at $1100{ }^{\circ} \mathrm{C}$. The addition of frit eliminated the continual drift in mass measurements seen for previous high $\mathrm{Na}$ (unwashed) tank samples during calcining. 
Table 2-1. Weight Percent Solids and Density for Tank 4 Samples [Number of Samples Included in Average]

\begin{tabular}{cc}
\hline Property & Tank 4 (\% RSD) \\
\hline Slurry Density & $1.35(0.8)[4]$ \\
Supernate Density & $1.33(0.4)[4]$ \\
Wt \% Total Solids & $37.3(0.3)[4]$ \\
$\quad$ (Slurry Basis) & \\
Wt \% Calcined Solids & $22.2(2.1)[4]$ \\
$\quad$ (Slurry Basis) & \\
Wt \% Dissolved Solids ${ }^{\mathrm{a}}$ & $35.0(0.2)[4]$ \\
(Supernate Basis) & \\
Wt \% Insoluble Solids & $3.62(2.9)^{\mathrm{c}}$ \\
$\quad$ (Slurry Basis) & \\
$\mathrm{Wt} \%$ Soluble Solids & $\mathrm{b}$ \\
$\quad$ (Slurry Basis) & $33.7(0.2)^{\mathrm{c}}$ \\
\hline
\end{tabular}

\footnotetext{
${ }^{a}$ Also known as Uncorrected Soluble Solids

${ }^{\mathrm{b}}$ Also known as Corrected Soluble Solids

$\mathrm{c}_{\% \mathrm{RSD}}$ here is more correctly defined as \% standard error for these calculated values.
}

Table 2-2 provides the anion results for the Tank 4 sample. The supernate sulfur result is calculated from total sulfur detected in the supernate by ICP-AES. The Al, B, Ca, Cr, K, Mn, Mo, Na, and P values also shown in this table were calculated from the ICP-AES data for the supernate and converted to a slurry basis using the insoluble solids content from Table 2-1. Other supernate elements measured were below the ICP-AES detection limits. 
Table 2-2. Supernate Analyses for Tank 4 Samples [Number of Samples Included in Average]

\begin{tabular}{cccc}
\hline Analyte & $\begin{array}{c}\text { Tank 4 } \\
\text { (\%RSD) } \\
\text { Molar }\end{array}$ & $\begin{array}{c}\text { Tank 4 } \\
\text { (\%RSD) } \\
\text { soluble mg/ } \\
\text { kg slurry }\end{array}$ & Method \\
\hline $\mathrm{NO}_{3}{ }^{-}$ & $1.37(0.5)[4]$ & $61600(0.5)[4]$ & IC \\
$\mathrm{NO}_{2}{ }^{-}$ & $1.25(0.5)[4]$ & $41900(0.5)[4]$ & IC \\
$\mathrm{SO}_{4}{ }^{2-}$ & $0.427(0.7)[4]$ & $29800(0.7)[4]$ & IC \\
$\mathrm{PO}_{4}{ }^{3-}$ & $<0.010$ & $<720$ & IC \\
$\mathrm{Br}^{-}$ & $<0.012$ & $<720$ & IC \\
$\mathrm{Cl}^{-}$ & $<0.028$ & $<720$ & IC \\
$\mathrm{CHO}_{2}{ }^{-}$ & $<0.022$ & $<720$ & IC \\
$\mathrm{C}_{2} \mathrm{O}_{4}{ }^{2-}$ & $<0.011$ & $<720$ & IC \\
$\mathrm{F}^{-}$ & $<0.052$ & $3960(0.3)[4]$ & ICP-AES \\
$\mathrm{Al}$ & $0.202(0.3)[4]$ & $13.4(0.7)[4]$ & ICP-AES \\
$\mathrm{B}$ & $0.00170(0.7)[4]$ & $4.09(5.5)[3]$ & ICP-AES \\
$\mathrm{Ca}$ & $0.000140(5.5)[3]$ & $495(0.2)[4]$ & ICP-AES \\
$\mathrm{Cr}$ & $0.0131(0.2)[4]$ & $840(8.7)[4]$ & ICP-AES \\
$\mathrm{K}$ & $0.0296(8.7)[4]$ & $3.92(4.0)[4]$ & ICP-AES \\
$\mathrm{Mn}$ & $0.0000982(4.0)[4]$ & $85.9(1.1)[4]$ & ICP-AES \\
$\mathrm{Mo}$ & $0.00123(1.1)[4]$ & $121000(1.0)[4]$ & ICP-AES \\
$\mathrm{Na}$ & $7.25(1.0)[4]$ & $262(0.7)[4]$ & ICP-AES \\
$\mathrm{P}$ & $0.0116(0.7)[4]$ & $12300(1.0)[4]$ & ICP-AES \\
$\mathrm{S}$ & $0.526(1.0)[4]$ & &
\end{tabular}

Table 2-3 provides the base measurements made on the Tank 4 sample. Total base represents the value determined from an inflection endpoint titration to $\mathrm{pH}$ 7. Free $\mathrm{OH}^{-}$represents the value determined after precipitation of carbonate with $\mathrm{BaCl}_{2}$ and titration to the first inflection endpoint between $\mathrm{pH} 11$ and 8 . Further titration of this treated sample to $\mathrm{pH} 7$ yields the value for other base.

Table 2-3. Base Analysis for Tank 4 Samples

[Number of Samples Included in Average]

\begin{tabular}{cc}
\hline Analyte & $\begin{array}{c}\text { Tank 4 } \\
\text { (\%RSD) } \\
\text { Molar }\end{array}$ \\
\hline Total Base & $2.71(3.7)[4]$ \\
Free $\mathrm{OH}^{-}$ & $1.5(1.8)[4]$ \\
Other Base & $0.3(1.5)[4]$ \\
\hline
\end{tabular}

The elemental concentrations determined by ICP-AES, ICP-MS, and CV-AA analyses are presented in Table 2-4. For the Tank 4 sample, results from both digestions have been combined where appropriate. 
Due to the use of $\mathrm{Zr}$ crucibles and $\mathrm{Na}_{2} \mathrm{O}_{2}$ in the alkali fusions, $\mathrm{Zr}$ and $\mathrm{Na}$ values, as well as other alkali metals, were determined from the aqua regia digestion. Mercury is also reported form the aqua regia digestion due to its volatility. In the case of $\mathrm{Be}, \mathrm{Li}, \mathrm{Sb}, \mathrm{Sn}$, and $\mathrm{V}$, both preparations yielded values below the detection limits, hence the lowest detection limit value was selected. Alkali fusion data was used to report values for $\mathrm{Al}$ and Si for the Tank 4 sample since the aqua regia preparation fails to dissolve all forms of these elements. The alkali fusion value for $\mathrm{Ca}$ is generally reported as well, but in these preps, the replicates were inconsistent, so the aqua regia digestion value is reported. The aqua regia prep values for $\mathrm{K}, \mathrm{P}, \mathrm{Ti}$ and $\mathrm{Zn}$ are reported because the alkali fusion preps gave values below the ICP-AES's quantification limits. Sulfur is also reported from only the aqua regia preps due to generally improved detection limits. ICP-MS analysis of the aqua regia digestion was also used to determine the concentrations of $\mathrm{Cd}, \mathrm{Ce}, \mathrm{Gd}, \mathrm{La}, \mathrm{Pb}$, and $\mathrm{U}$. In the case of $\mathrm{Ce}$ the distribution of isotopes was not natural but rather the result of fission product yields from U-235. Hence the sum of the respective isotopic masses was used to determine the reported concentrations for $\mathrm{Ce}$ and $\mathrm{U}$. The $\mathrm{U}$ value reported here from ICP-MS compares to a value determined by ICP-AES of $1.02 \mathrm{wt} \%$ of total solids. For Cd, Gd, and $\mathrm{Pb}$, the reported value was determined from all measured values calculated using the various isotopes' natural abundance. In the case of La-139 a single isotope has 100\% natural abundance and was used to calculate the value given in the table.

Table 2-4. Elemental Concentrations* in Tank 4 Samples in Wt \% of Total Solids (\%RSD) [Number of Samples Included in Average]

\begin{tabular}{|c|c|c|c|}
\hline Element & Tank 4 & Element & Tank 4 \\
\hline $\mathrm{Al}$ & $1.22(0.9)[4]$ & $\mathrm{Mn}$ & $0.171(1.2)[8]$ \\
\hline $\mathrm{B}$ & $0.0106(5.9)[3]$ & Mo & $0.0234(7.0)[8]$ \\
\hline $\mathrm{Ba}$ & $0.0187(1.3)[8]$ & $\mathrm{Na}$ & $31.5(0.6)[4]$ \\
\hline $\mathrm{Be}$ & $<0.0024$ & $\mathrm{Ni}$ & $0.827(1.5)[8]$ \\
\hline $\mathrm{Ca}$ & $0.125(0.7)[4]$ & $\mathrm{P}$ & $0.110(2.0)[4]$ \\
\hline $\mathrm{Cd}^{\ddagger}$ & $0.000679(7.1)[2]$ & $\mathrm{Pb}^{\ddagger}$ & $0.00679(7.2)[4]$ \\
\hline $\mathrm{Ce}^{*}$ & $0.0144(2.8)[4]$ & $\mathrm{S}$ & $3.68(0.6)[4]$ \\
\hline $\mathrm{Cr}$ & $0.141(2.3)[8]$ & $\mathrm{Sb}$ & $<0.011$ \\
\hline $\mathrm{Cu}$ & $0.0107(7.2)[8]$ & $\mathrm{Si}$ & $0.170(7.6)[4]$ \\
\hline $\mathrm{Fe}$ & $3.44(0.8)[8]$ & $\mathrm{Sn}$ & $<0.013$ \\
\hline $\mathrm{Gd}^{\ddagger}$ & $0.00159(7.0)[4]$ & $\mathrm{Sr}$ & $0.00686(3.3)[8]$ \\
\hline $\mathrm{Hg}^{\wedge}$ & $0.00274(11)[4]$ & $\mathrm{Ti}$ & $0.00262(4.7)[4]$ \\
\hline $\mathrm{K}$ & $0.258(6.8)[4]$ & $\mathrm{U}^{* *}$ & 0.988 (1.1) [4] \\
\hline $\mathrm{La}^{\ddagger}$ & $0.0133(2.1)[4]$ & $\mathrm{V}$ & $<0.0049$ \\
\hline $\mathrm{Li}$ & $<0.012$ & $\mathrm{Zn}$ & $0.00349(1.1)[4]$ \\
\hline $\mathrm{Mg}$ & $0.0137(6.1)[4]$ & $\mathrm{Zr}$ & $0.0411(0.9)[4]$ \\
\hline
\end{tabular}

The fission product noble metal and silver concentrations are given in Table 2-5. The values were calculated from ICP-MS data using an Excel spreadsheet. This spreadsheet uses the fission yield for each isotope to account for the mass contribution from isotopes in the tank that could not be measured because 
isotopes of natural $\mathrm{Cd}$ interfere at this mass. An example of this is the measurement at mass 110 , which is comprised of Pd-110 and Cd-110. The uncertainties were analyzed using statistical techniques appropriate for replicate measurements of non-highly correlated data.

Table 2-5. Noble Metal Fission Products and Silver Concentrations in Tank 4 in Wt \% of Total Solids (\%RSD)

\begin{tabular}{cc}
\hline Element & Tank 4 \\
\hline $\operatorname{Ag}(-107,-109)$ & $0.00161(2.0)$ \\
$\operatorname{Pd}(-105,-106,-107,-108,-110)$ & $0.00293(2.0)$ \\
$\operatorname{Rh}(-103)$ & $0.00577(2.7)$ \\
$\mathrm{Ru}(-101,-102,-104)$ & $0.0237(0.4)$ \\
\hline
\end{tabular}

\subsection{Rheology Methods}

Rheological properties of radioactive samples are determined using a Haake M5/RV30 rotoviscometer. The M5/RV30 is a Searle sensor system, where the bob rotates and the cup is fixed. The torque and rotational speed of the bob are measured. Heating/cooling of the cup/sample/bob is through the holder that holds the cup. The shear stress is determined from the torque measurement and is independent of the rheological properties. Conditions that impact the measured torque are; slip (material does not properly adhere to the rotor or cup), phase separation (buildup of a liquid layer on the rotor), sedimentation (particles settling out of the shearing zone), homogeneous sample (void of air), lack of sample (gap not filled), excess sample (primarily impacts rheologically thin fluids), completely filling up the void below the bob (air buffer that is now filled with fluid) and Taylor vortices. The first five items yield lower stresses and the last three add additional stresses. The shear rate is geometrically determined using the equations of change (continuity and motion) and is that for a Newtonian fluid. This assumption also presupposes that the flow field is fully developed and the flow is laminar. The shear rate can be calculated for a non-Newtonian fluid using the measured data and fitting this data to the rheological model or corrected as recommended by Darby'. In either case, for shear thinning non-Newtonian fluids typical of Savannah River Site (SRS) sludge wastes, the corrected shear rates are greater than their corresponding Newtonian shear rates, resulting in a thinner fluid. Correcting the flow curves was not performed in this task; therefore, the results are biased high.

The bob typically used for measuring tank sludge is the MV I rotor. The shape, dimensions, and geometric constants for the MV I rotor is provided in Table 2-6.

Prior to performing the measurements, the rotors and cups were inspected for physical damage. The torque/speed sensors and temperature bath verified for functional operability using a bob/cup combination with a National Institute of Standards and Technology (NIST) traceable Newtonian oil standard, using the MV I rotor. The resulting flow curves were then fitted as a Newtonian fluid and this calculated viscosity must be within $\pm 10 \%$ of the reported NIST viscosity at a given temperature for the system to be considered functionally operable. A N10 oil standard was used to verify system operability prior to the sludge measurements.

The flow curves for the sludge are fitted to the down curves using the Bingham Plastic rheological model, Equation (1), where $\tau$ is the measured stress $(\mathrm{Pa}), \tau_{\mathrm{o}}$ is the Bingham Plastic yield stress $(\mathrm{Pa}), \mu_{\infty}$ is 
the plastic viscosity $(\mathrm{Pa} \cdot \mathrm{sec})$, and $\cdot \gamma$ is the measured shear rate $\left(\mathrm{sec}^{-1}\right)$. During all these measurements, the sample remained in the cup for the $2^{\text {nd }}$ measurement, due to the limited sample availability.

$$
\tau=\tau_{o}+\mu_{\infty} \dot{\gamma}
$$

Table 2-6. MV I Rotor Specifications and Flow Curve Program

\begin{tabular}{|c|c|c|}
\hline \multirow[t]{2}{*}{ Rotor Design } & \multicolumn{2}{|l|}{ Dimensions and Flow Curve Program } \\
\hline & Rotor Type & MV I \\
\hline & Rotor radius $-\mathrm{R}_{\mathrm{i}}(\mathrm{mm})$ & 20.04 \\
\hline & Cup Radius - $\mathrm{R}_{\mathrm{a}}(\mathrm{mm})$ & 21.0 \\
\hline & Height of rotor -L (mm) & 60 \\
\hline & Sample Volume $\left(\mathrm{cm}^{3}\right)$ minimum & 40 \\
\hline & A factor $(\mathrm{Pa} / \%$ torque $)$ & 3.22 \\
\hline & $\mathrm{M}$ factor $\left(\mathrm{s}^{-1} / \% \mathrm{RPM}\right)$ & 11.7 \\
\hline & Shear rate range $\left(\mathrm{s}^{-1}\right)$ & $0-600$ \\
\hline & Ramp up time (min) & 5 \\
\hline & Hold time (min) & 1 \\
\hline & Ramp down time (min) & 5 \\
\hline
\end{tabular}

\subsection{Rheology Results}

Figure 2-1 through Figure 2-6 provide the shear stress versus shear rate flow curves for Tank 4, decanted Tank 51-E1, and the blend of Tank 4 with the decanted Tank 51-E1 sample. Refer to Section 2.5 for details on the blend ratio. The resulting plastic viscosities in $\mathrm{cP}$ and yield stresses in $\mathrm{Pa}$ are summarized in Table 2-7. The Tank 4 sample had virtually no yield stress, so this value is reported as zero.

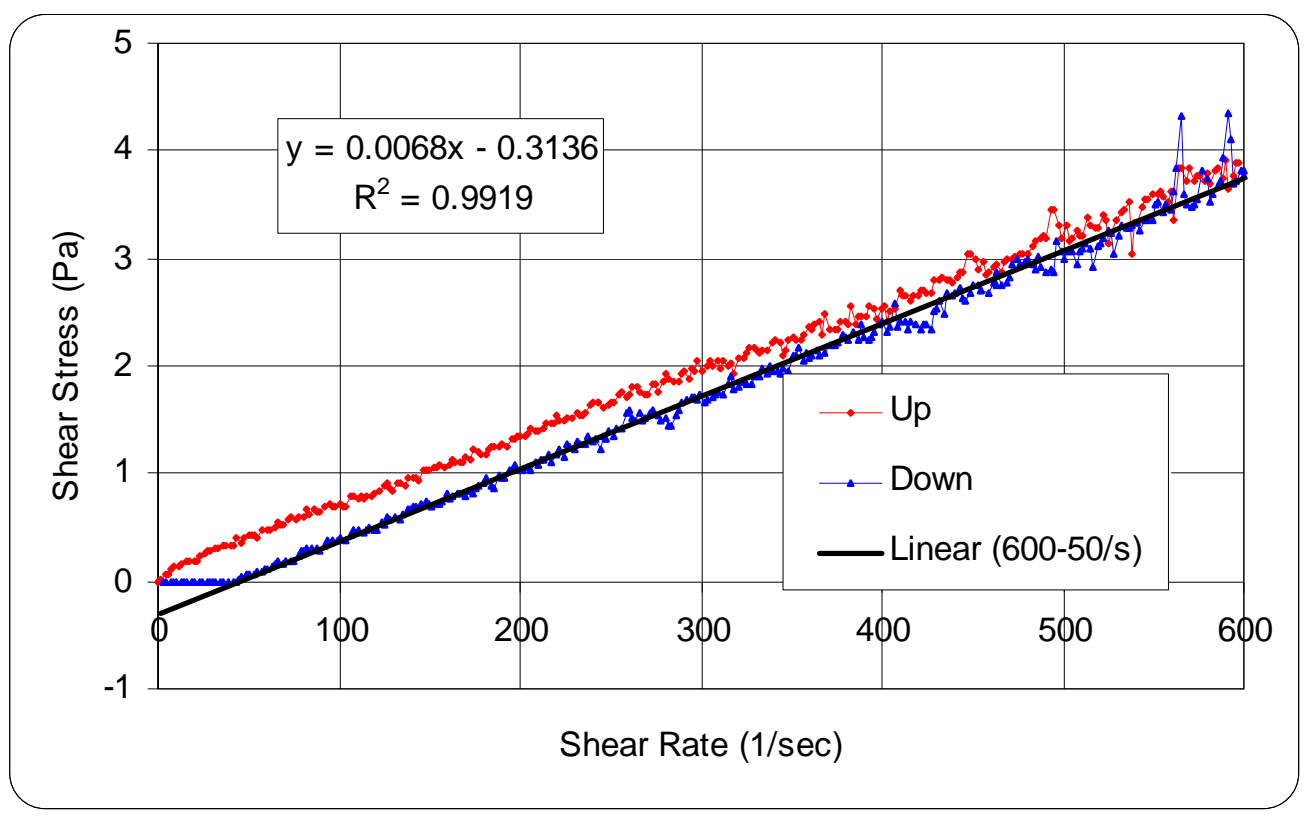

Figure 2-1. Tank 4 Shear Stress vs. Shear Rate Replicate 1 


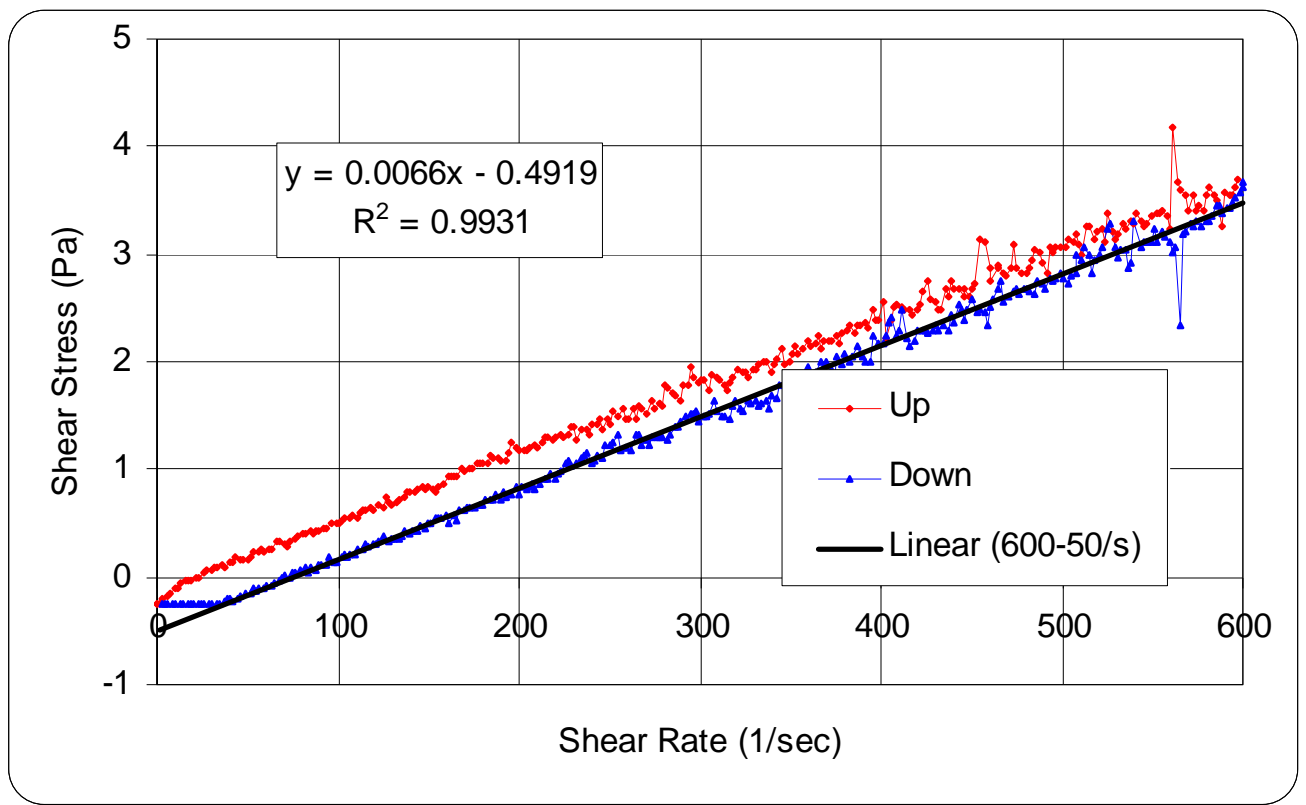

Figure 2-2. Tank 4 Shear Stress vs. Shear Rate Replicate 2

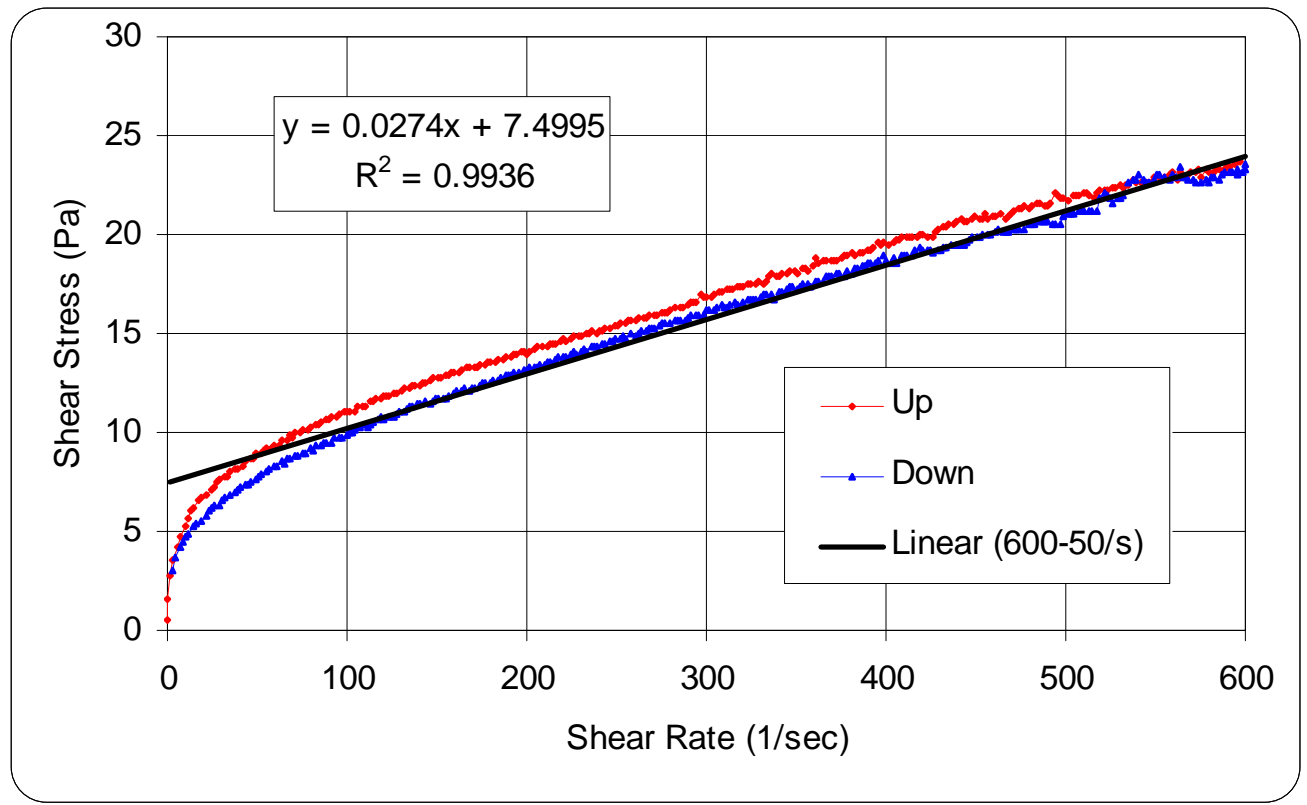

Figure 2-3. Decanted Tank 51-E1 (43\% of total volume removed) Shear Stress vs. Shear Rate Replicate 1 


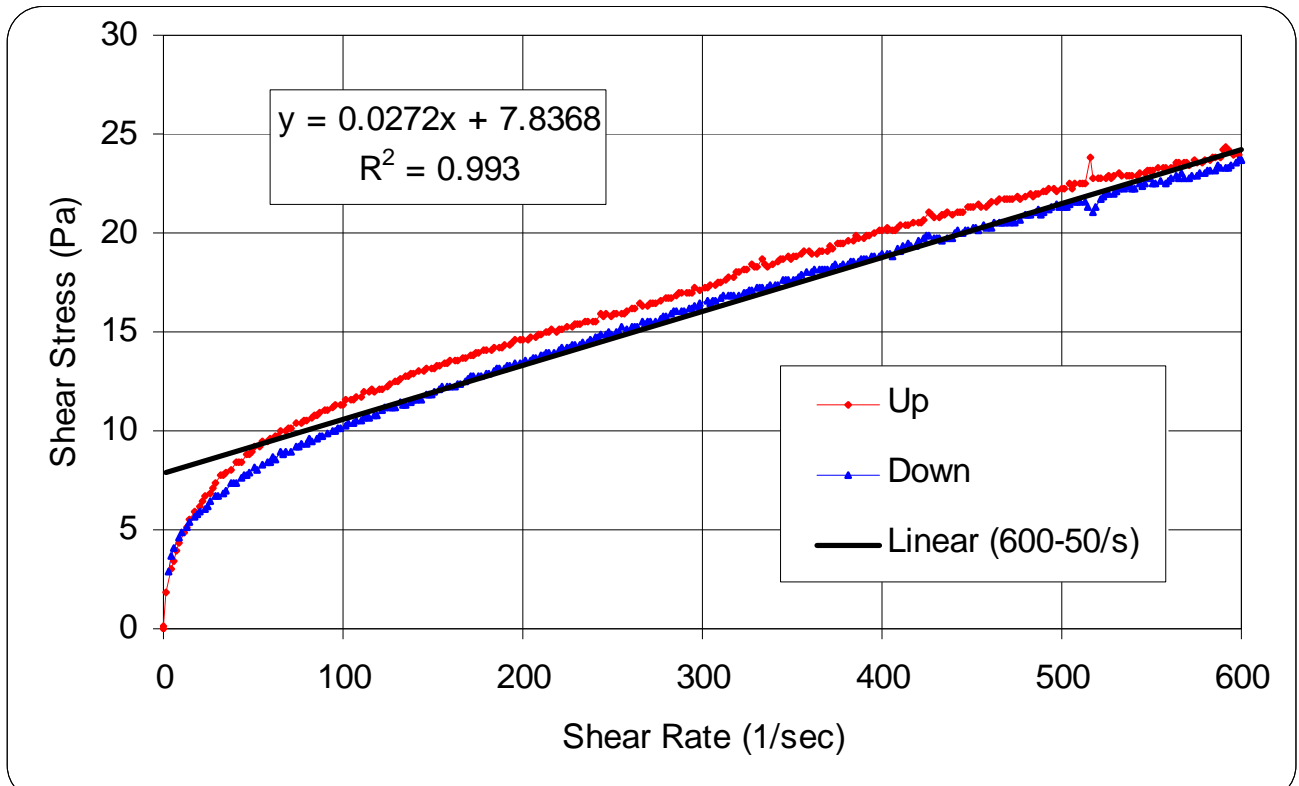

Figure 2-4. Decanted Tank 51-E1 (43\% of total volume removed) Shear Stress vs. Shear Rate Replicate 2

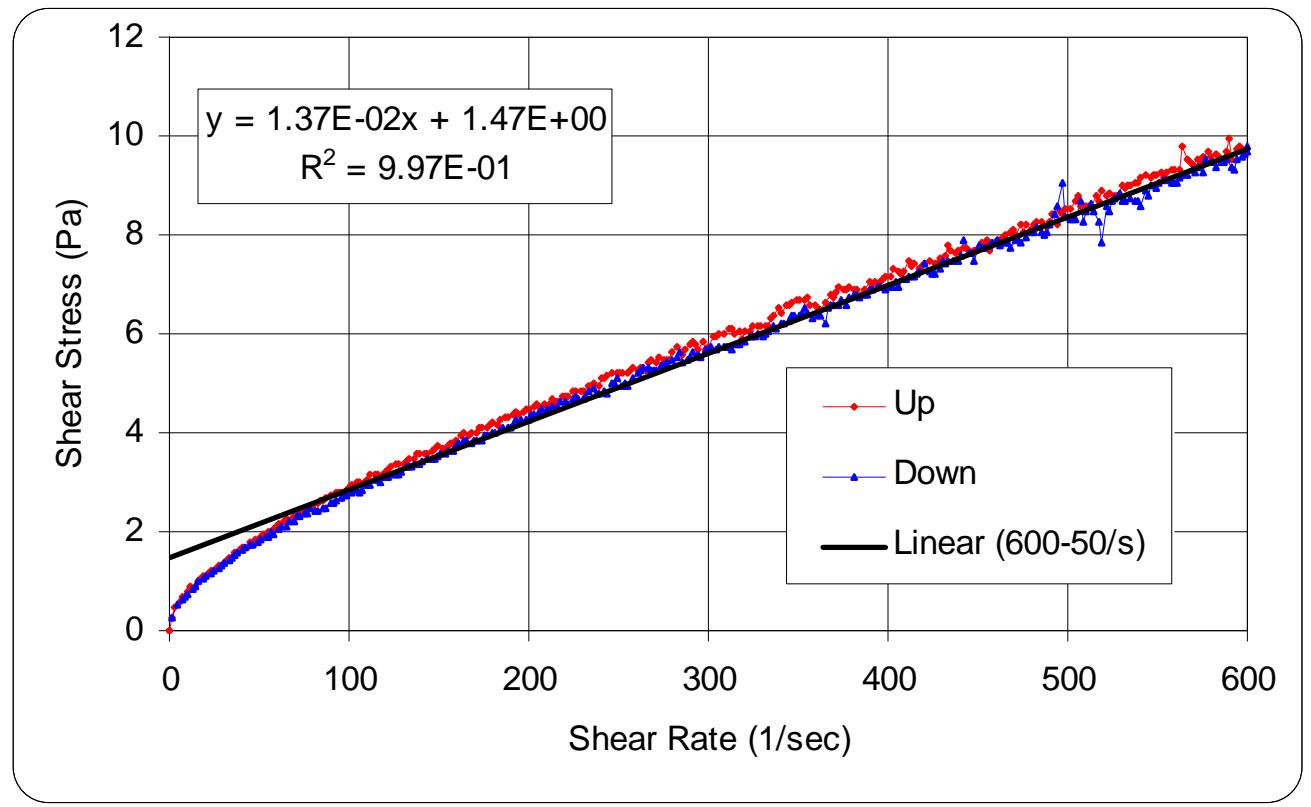

Figure 2-5. Tank 4/Decanted Tank 51-E1 Blend Shear Stress vs. Shear Rate Replicate 1 


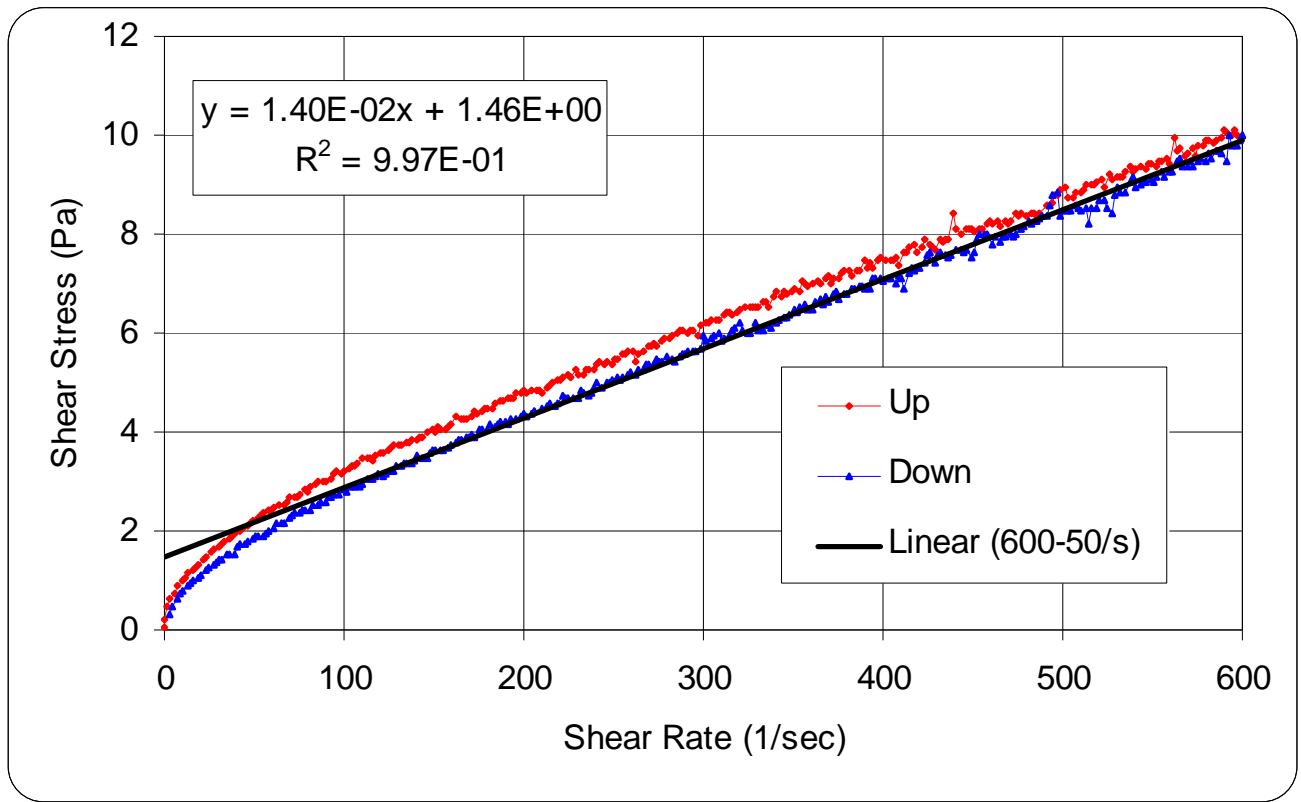

Figure 2-6. Tank 4/Decanted Tank 51-E1 Blend Shear Stress vs. Shear Rate Replicate 2

Table 2-7. Rheology Summary for Tank 4, Decanted Tank 51-E1, and Tank 4/Decanted Tank 51-E1 Blend.

\begin{tabular}{lcc}
\hline \multicolumn{1}{c}{ Tank - Replicate } & $\begin{array}{c}\text { Plastic } \\
\text { Viscosity } \\
\text { (cP) }\end{array}$ & $\begin{array}{c}\text { Yield } \\
\text { Stress } \\
\mathbf{( P a )}\end{array}$ \\
\hline Tank 4-1 & 6.8 & $0^{*}$ \\
Tank 4 - & 6.6 & $0^{*}$ \\
Tank 4-average & 6.7 & 0 \\
\hline Tank 51-E1 Decanted - 1 & 27.2 & 7.5 \\
Tank 51-E1 Decanted - & 27.4 & 7.8 \\
Tank 51-E1 Decanted - average & 27.3 & 7.7 \\
\hline Tank 4/51-E1 Blend - 1 & 13.7 & 1.5 \\
Tank 4/51-E1 Blend - & 14.0 & 1.5 \\
Tank 4/51-E1 Blend - average & 13.9 & 1.5 \\
\hline
\end{tabular}

\subsection{Settling Study Methods}

A comparison of settling between a decanted sample of Tank 51 and Tank 4 was requested by LWE. For the Tank 51 portion, the Tank 51-E1 sample was decanted. The target decant amount, per LWE, was $45 \%$ of the total volume. However, only $43 \%$ of the total volume could be decanted without disturbing the settled solids. It should be noted that the sample had been undisturbed for several weeks prior to this decant. Two $50 \mathrm{~mL}$ graduated cylinders were used as the settling vessels. The decanted Tank 51 slurry was added to the $50 \mathrm{~mL}$ mark in the first cylinder. The decanted Tank 51 slurry was added to the $29 \mathrm{~mL}$ mark in the second cylinder followed by $21 \mathrm{~mL}$ of Tank 4 slurry. A ratio of 2.1 to 1 of Tank 51 insoluble 
solids to Tank 4 insoluble solids was targeted. Both cylinders were mixed by shaking and left undisturbed. The volumetric sludge level was recorded at least daily during working days.

\subsection{Settling Study Results}

Figure 2-7 provided the results of the settling study for both the decanted Tank 51-E1 sample and a blend of this sample with Tank 4 slurry. Settled volume was recorded in $\mathrm{mL}$ and plotted versus time in days.

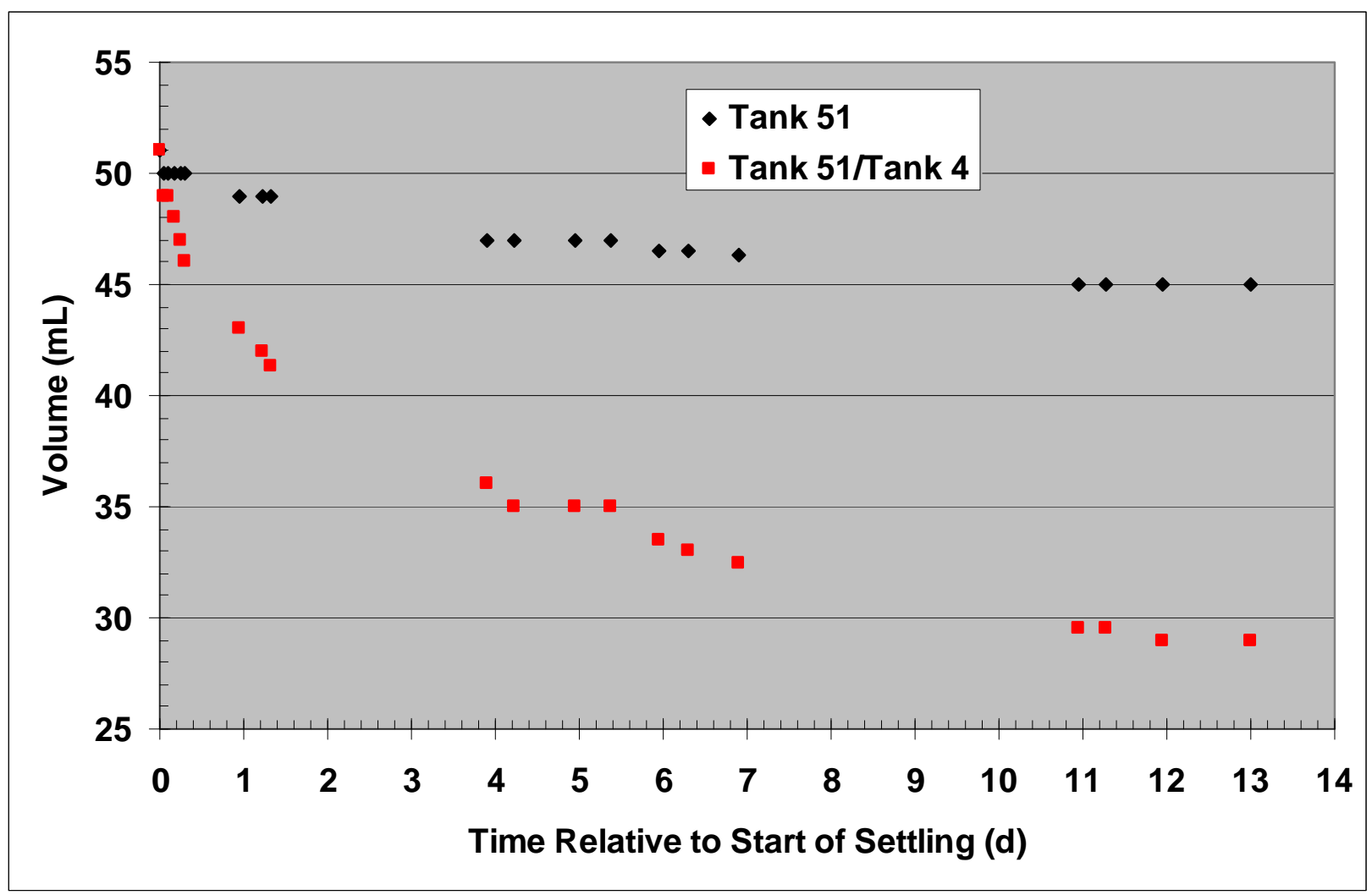

Figure 2-7. Comparison of settled volume (mL) vs. time (days) for a decanted Tank 51-E1 sample and a blend of Tank 51-E1 and Tank 4.

\subsection{Modeling Study Methods}

The OLI (OLI Systems, Inc.) StreamAnalyzer was used to model the chemistry of the Tank 4 sample to determine the likelihood that sulfate could exist in this sample as insoluble Burkeite $\left(2 \mathrm{Na}_{2} \mathrm{SO}_{4} \cdot \mathrm{Na}_{2} \mathrm{CO}_{3}\right)$. StreamAnalyzer was used with the Public, Corrosion, Geochemisty, and WTPBase thermodynamic databases. The Tank 4 sample supernate and total slurry species compositions were used to generate an overall composition vector. The original slurry (wt $\%$ of solids) measurements were converted to a per $\mathrm{kg}$ slurry basis. The values used are shown in Table 2-8. These values were converted to the OLI inputs in $\mathrm{mmol} / \mathrm{kg}$ slurry shown in the last two columns. Note that these values do not necessarily match the final reported values in this report; the OLI calculations were performed in parallel with the final data validation, so preliminary values had to be used. 
SRNL-STI-2009-00544

Revision 0

Table 2-8. Input Concentrations for OLI StreamAnalyzer Model of Tank 4 Slurry

\begin{tabular}{|c|c|c|c|c|c|c|}
\hline Species & $\begin{array}{c}\text { Slurry } \\
\text { (wt } \% \text { of total dried } \\
\text { solids) }\end{array}$ & $\begin{array}{l}\text { Total Slurry } \\
\text { (mg/kg slurry) }\end{array}$ & $\begin{array}{c}\text { Supernate } \\
\text { (mg/kg slurry) }\end{array}$ & $\begin{array}{c}\text { Total Slurry } \\
\text { (mmol } / \mathrm{kg} \\
\text { slurry) }\end{array}$ & $\begin{array}{l}\text { Supernate } \\
\text { (mmol/kg } \\
\text { slurry) }\end{array}$ & $\begin{array}{l}\text { Undissolved } \\
\text { Solids } \\
\text { (mmol/kg } \\
\text { slurry) }\end{array}$ \\
\hline Al & 1.22 & 4551 & 3964 & 169 & 147 & 22 \\
\hline B & 0.0106 & 39.5 & 13.4 & 3.66 & 1.24 & 2.42 \\
\hline Ba & 0.0187 & 69.8 & & 0.508 & & 0.508 \\
\hline $\mathrm{Ca}$ & 0.125 & 466 & 4.56 & 11.6 & 0.114 & 11.5 \\
\hline Cd & 0.000679 & 2.53 & & 0.0225 & & 0.0225 \\
\hline Ce & 0.0144 & 53.7 & & 0.383 & & 0.383 \\
\hline $\mathrm{Cr}$ & 0.141 & 526 & 495 & 10.1 & 9.52 & 0.58 \\
\hline $\mathbf{C u}$ & 0.0107 & 39.9 & & 0.628 & & 0.628 \\
\hline $\mathbf{F e}$ & 3.44 & 12831 & 21.5 & 230 & 0.385 & 230 \\
\hline Gd & 0.00159 & 5.93 & & 0.0377 & & 0.0377 \\
\hline Hg & 0.00274 & 10.2 & & 0.0510 & & 0.0510 \\
\hline $\mathbf{K}$ & 0.258 & 962 & 841 & 24.6 & 21.5 & 3.1 \\
\hline $\mathbf{L a}$ & 0.0133 & 49.6 & & 0.357 & & 0.357 \\
\hline Mg & 0.0137 & 51.1 & & 2.10 & & 2.10 \\
\hline Mn & 0.171 & 638 & 3.92 & 11.6 & 0.0714 & 11.5 \\
\hline Mo & 0.0234 & 87.3 & 85.9 & 0.910 & 0.895 & 0.015 \\
\hline Na(Original) & 31.5 & 117495 & & 5111 & & \\
\hline $\mathrm{Na}$ (Adjusted) & (to supernate value) & 121205 & 121205 & 5272 & 5272 & 0 \\
\hline $\mathbf{N i}$ & 0.827 & 3085 & & 52.6 & & 52.6 \\
\hline $\mathbf{P}$ & 0.11 & 410 & 262 & 13.2 & 8.46 & 5.7 \\
\hline $\mathbf{P b}$ & 0.00679 & 25.3 & & 0.122 & & 0.122 \\
\hline $\mathbf{S}$ & 3.68 & 13726 & 12277 & 428 & 383 & 45 \\
\hline Si & 0.17 & 634 & & 22.6 & & 22.6 \\
\hline $\mathrm{Sr}$ & 0.00689 & 25.7 & & 0.293 & & 0.293 \\
\hline $\mathbf{T i}$ & 0.00262 & 9.77 & & 0.204 & & 0.204 \\
\hline $\mathbf{U}$ & 0.988 & 3685 & & 15.5 & & 15.5 \\
\hline Zn & 0.00349 & 13.0 & & 0.199 & & 0.199 \\
\hline $\mathrm{Zr}$ & 0.0411 & 153 & & 1.68 & & 1.68 \\
\hline \multicolumn{7}{|c|}{$\begin{array}{c}\text { Supernate } \\
(\mathrm{mol} / \mathrm{L})\end{array}$} \\
\hline $\mathrm{NO}_{3}{ }^{-}$ & 1.42 & NA & 64051 & NA & 1033 & 0 \\
\hline $\mathrm{NO}_{2}^{-}$ & 1.30 & NA & 43508 & NA & 946 & 0 \\
\hline $\mathrm{SO}_{4}{ }^{2-}$ & 0.526 & NA & 36780 & NA & 383 & 0 \\
\hline $\mathrm{PO}_{4}{ }^{3-}$ & 0.0116 & NA & 803 & NA & 8.46 & 0 \\
\hline $\mathrm{CO}_{3}{ }^{2-}$ calc. & 0.869 & NA & 37925 & NA & 632 & 0 \\
\hline $\mathbf{O H}^{-}$ & 1.50 & NA & 18558 & NA & 1091 & 0 \\
\hline $\mathrm{Cl}^{-}$ & 0.0170 & NA & 438 & NA & 12.4 & 0 \\
\hline $\mathrm{C}_{2} \mathrm{O}_{4}{ }^{2-}$ & 0.00410 & NA & 263 & NA & 2.98 & NM \\
\hline $\mathbf{F}^{-}$ & 0.00500 & NA & 69.1 & NA & 3.64 & 0 \\
\hline
\end{tabular}

$\mathrm{NA} \equiv$ not applicable, $\mathrm{NM} \equiv$ not measured, $\mathrm{NC} \equiv$ not calculated 
Table 2-9. Input Parameters for OLI StreamAnalyzer Model of Tank 4 Slurry

\begin{tabular}{rc}
\hline Slurry Density kg/L & 1.350 \\
Supernate Density kg/L & 1.326 \\
Total Solids wt $\%$ & $37.30 \%$ \\
Soluble Solids wt $\%$ & $33.76 \%$ \\
Insoluble Solids wt $\%$ & $3.54 \%$ \\
Dissolved Solids wt $\%$ & $35.00 \%$ \\
\hline
\end{tabular}

\subsection{Modeling Study Results}

The $\mathrm{Na}$ amount measured in the slurry was lower than the supernate measurement, so the supernate value was assumed for the slurry. The carbonate value was calculated to balance the charge in the supernate. The Na values were also adjusted for formation of Burkeite. The sulfur concentration in the total slurry was $13726 \mathrm{mg} / \mathrm{kg}$ slurry and the supernate value was $12277 \mathrm{mg} / \mathrm{kg}$ slurry, suggesting that about 1449 $\mathrm{mg} / \mathrm{kg}$ slurry of undissolved sulfur existed in the slurry. Because Tank 4 was a Burkeite-containing tank, this undissolved sulfur was assumed to be Burkeite; the only other sulfate compound predicted to be insoluble was $\mathrm{BaSO}_{4}$ and there is insufficient $\mathrm{Ba}$ to account for the amount of undissolved sulfate measured. Some of the assumed carbonate $(1351 \mathrm{mg} / \mathrm{kg})$ was precipitated in the model to form this Burkeite. The total carbonate was not adjusted for the charge balance because the amount precipitated was relatively small (1351 of $37925 \mathrm{mg} / \mathrm{kg}$ ) and OLI closes the charge balance by adjusting the dissolved species. The composition of the Tank 4 sample was simulated in OLI at $35^{\circ} \mathrm{C}$ because of a databank limitation that prevents the formation of Burkeite below $31^{\circ} \mathrm{C}$.

The results of the OLI model are compared to the measured concentrations in Table 2-10 and Table 2-11. The modeling results demonstrate that the existence of Burkeite in the Tank 4 sample is possible. 
Table 2-10. Predicted Tank 4 Composition

\begin{tabular}{|c|c|c|c|c|c|c|}
\hline Species & $\begin{array}{c}\text { Measured } \\
\text { Total } \\
\text { Slurry } \\
\text { (mmol/kg } \\
\text { slurry) }\end{array}$ & $\begin{array}{c}\text { (mmol/kg } \\
\text { slurry) }\end{array}$ & $\begin{array}{l}\text { Measured } \\
\text { Undissolved } \\
\text { Solids } \\
\\
\text { (mmol/kg } \\
\text { slurry) }\end{array}$ & $\begin{array}{c}\text { OLI } \\
\text { Predicted } \\
\text { Total } \\
\text { Slurry } \\
\text { (mmol/kg } \\
\text { slurry) }\end{array}$ & $\begin{array}{c}\text { OLI } \\
\text { Predicted } \\
\text { Supernate } \\
\\
\text { (mmol/kg } \\
\text { slurry) }\end{array}$ & $\begin{array}{c}\text { OLI } \\
\text { Predicted } \\
\text { Undissolved } \\
\text { Solids } \\
\text { (mmol/kg } \\
\text { slurry) }\end{array}$ \\
\hline Al & 169 & 147 & 22 & 169 & 162 & 7 \\
\hline $\mathbf{B}$ & 3.66 & 1.24 & 2.42 & 3.65 & 3.65 & 0 \\
\hline Ba & 0.508 & & 0.508 & 0.507 & 0 & 0.507 \\
\hline Ca & 11.6 & 0.114 & 11.5 & 11.6 & 0 & 11.6 \\
\hline Cd & 0.0225 & & 0.0225 & 0.0225 & 0.0225 & 0 \\
\hline Ce & 0.383 & & 0.383 & 0.382 & 0 & 0.382 \\
\hline $\mathrm{Cr}$ & 10.1 & 9.52 & 0.58 & 10.1 & 9.50 & 0.59 \\
\hline $\mathbf{C u}$ & 0.628 & & 0.628 & 0.627 & 0.0436 & 0.583 \\
\hline Fe & 230 & 0.385 & 230 & 230 & 0 & 230 \\
\hline Gd & 0.0377 & & 0.0377 & 0.0376 & 0.0376 & 0 \\
\hline Hg & 0.0510 & & 0.0510 & 0.0509 & 0.0509 & 0 \\
\hline $\mathbf{K}$ & 24.6 & 21.5 & 3.1 & 24.6 & 24.6 & 0 \\
\hline $\mathbf{L a}$ & 0.357 & & 0.357 & 0.356 & 0 & 0.356 \\
\hline Mg & 2.10 & & 2.10 & 2.10 & 0 & 2.10 \\
\hline Mn & 11.6 & 0.0714 & 11.5 & 11.6 & 0.696 & 10.9 \\
\hline Mo & 0.910 & 0.895 & 0.015 & 0.908 & 0.908 & 0 \\
\hline $\mathbf{N a}$ & 5272 & 5272 & 0 & 5379 & 5243 & 136 \\
\hline $\mathrm{Ni}$ & 52.6 & & 52.6 & 52.5 & 0 & 52.5 \\
\hline $\mathbf{P}$ & 13.2 & 8.46 & 5.7 & 13.2 & 10.4 & 2.74 \\
\hline $\mathbf{P b}$ & 0.122 & & 0.122 & 0.122 & 0.122 & 0 \\
\hline $\mathrm{S}$ & 428 & 383 & 45 & 427 & 383 & 44.2 \\
\hline Si & 22.6 & & 22.6 & 22.6 & 14.9 & 7.67 \\
\hline $\mathrm{Sr}$ & 0.293 & & 0.293 & 0.292 & 0.00168 & 0.291 \\
\hline $\mathbf{T i}$ & 0.204 & & 0.204 & 0.204 & 0 & 0.203 \\
\hline $\mathbf{U}$ & 15.5 & & 15.5 & 15.5 & 0.00372 & 15.5 \\
\hline Zn & 0.199 & & 0.199 & 0.199 & 0 & 0.199 \\
\hline $\mathrm{Zr}$ & 1.68 & & 1.68 & 1.68 & 0 & 1.68 \\
\hline $\mathrm{NO}_{3}^{-}$ & 1033 & 1033 & 0 & 1031 & 1031 & 0 \\
\hline $\mathrm{NO}_{2}^{-}$ & 946 & 946 & 0 & 944 & 944 & 0 \\
\hline $\mathrm{SO}_{4}^{2-}$ & 428 & 383 & 45 & 427 & 383 & 44.2 \\
\hline $\mathrm{PO}_{4}^{3-}$ & 13.2 & 8.46 & 4.74 & 13.2 & 10.4 & 2.74 \\
\hline $\mathrm{CO}_{3}{ }^{2-}$ calc. & 632 & 632 & 0 & 631 & 609 & 22.2 \\
\hline $\mathbf{O H}^{-}$ & & 1091 & & $\mathrm{NC}$ & $\mathrm{NC}$ & $\mathrm{NC}$ \\
\hline $\mathrm{Cl}^{-}$ & 12.4 & 12.4 & 0 & 12.4 & 12.4 & 0 \\
\hline $\mathrm{C}_{2} \mathrm{O}_{4}{ }^{2}$ & NM & 2.98 & NM & 2.97 & 2.97 & 0 \\
\hline $\mathbf{F}^{-}$ & 3.64 & 3.64 & 0 & 3.63 & 2.72 & 0.913 \\
\hline
\end{tabular}

$\mathrm{NM} \equiv$ not measured, $\mathrm{NC} \equiv$ not calculated

Table 2-11. Predicted Tank 4 Properties

\begin{tabular}{ccc}
\hline Parameter & Measured & Predicted \\
\hline Slurry Density kg/L & 1.350 & 1.334 \\
Supernate Density kg/L & 1.326 & 1.294 \\
Total Solids wt\% & 37.30 & 36.25 \\
Soluble Solids wt $\%$ & 33.76 & 32.40 \\
Insoluble Solids wt $\%$ & 3.54 & 3.85 \\
Dissolved Solids wt $\%$ & 35.00 & 33.70 \\
\hline
\end{tabular}




\subsection{Washing Study Methods}

The blend of decanted Tank 51 and Tank 4 used for the settling study was used in a washing study, as requested by LWE in light of their concern about the S concentration in Tank 4 and specific evidence indicating that some of this $\mathrm{S}$ is insoluble or undissolved. The sludge was divided equally into two centrifuge tubes. The samples were then centrifuged for approximately $15-35$ minutes, or until the solids were below the $5 \mathrm{~mL}$ mark on the centrifuge tube, then as much supernate as possible was removed without disturbing the solids. Water was then added and a vortex mixer was used to mix the decanted slurry and wash water. Again supernate was decanted. This process was repeated two more times for a total of three washes and four decants. Approximately, 3x dilutions were targeted for each wash -10 to $12 \mathrm{~mL}$ of decanted slurry diluted to 35 to $40 \mathrm{~mL}$ with deionized water. Initial slurry masses, decant masses, and wash water masses are given in Table 2-12.

Table 2-12. Sulfate Washing Slurry Masses, Decant Masses, and Wash Water Masses

\begin{tabular}{lcc}
\hline \multicolumn{1}{c}{ Operation } & $\begin{array}{c}\text { Replicate 1 } \\
\text { (g) }\end{array}$ & $\begin{array}{c}\text { Replicate 2 } \\
\text { (g) }\end{array}$ \\
\hline Initial Slurry Mass & 29.25 & 30.68 \\
Initial Decant Mass & 10.37 & 12.21 \\
\hline Wash A (water) Added & 24.31 & 24.46 \\
Decant A Removed & 32.64 & 32.80 \\
\hline Wash B (water) Added & 26.20 & 27.17 \\
Decant B Removed & 26.93 & 27.74 \\
\hline Wash C (Water) Added & 20.77 & 21.45 \\
Decant C Removed & 23.79 & 23.75 \\
\hline Remaining Slurry Mass & 6.80 & 7.26 \\
\hline
\end{tabular}

The decanted supernates were then diluted and submitted to SRNL AD for anion analysis by IC and elementals by ICP-AES. Also, the densities of the decanted supernates were measured, but it was not possible to measure the densities or weight percent solids of the intermediate or final slurry samples. The slurry remaining after the final decant was digested with a modified aqua regia digestion and submitted to SRNL-AD for elemental analysis by ICP-AES. There were trace solids left following the digestion which were not analyzed due to time constraints, but in the past these solids have generally been found to be undissolved Al (Boehmite).

\subsection{Washing Study Results}

The initial slurry composition was not measured because of the small amount of sample and time constraints. However, both Tank 4 and Tank 51 (prior to decanting) were characterized separately. This data was used to calculate a slurry composition for the mixture using the same blend ratio as noted in Section 2.5. The OLI model assumptions employed were 1) that $\mathrm{Fe}$ and $U$ concentrations in the supernate are zero, and 2) nitrate and nitrite concentrations in the insoluble species are zero. 
Table 2-13. Major Elements (>1,000 $\mathrm{mg} / \mathrm{kg}$ ), Nitrite and Nitrate in the Decanted-Tank 51/Tank 4 Blend Prior to Washing Calculated by OLI From Analyses for Tank 51 and Tank 4

\begin{tabular}{cc}
\hline Species & $\begin{array}{c}\text { Concentration } \\
(\mathbf{m g} / \mathbf{k g})\end{array}$ \\
\hline $\mathrm{Al}$ (total) & 19000 \\
$\mathrm{Al}$ (soluble) & 12400 \\
$\mathrm{Fe}$ (total) & 10500 \\
$\mathrm{Na}$ (total) & 133000 \\
$\mathrm{~S}$ (total) & 6230 \\
$\mathrm{~S}$ (soluble) & 5450 \\
$\mathrm{U}$ (total) & 2360 \\
$\mathrm{NO}_{2}^{-}$ & 42000 \\
$\mathrm{NO}_{3}^{-}$ & 55700 \\
\hline
\end{tabular}

The decant analytical results for each replicate are given in Table 2-14. Density measurements are also provided.

Table 2-14. Analytical Results for the Decants from Washing the Decanted-Tank 51/Tank 4 Sludge Blend

\begin{tabular}{|c|c|c|c|c|}
\hline Species (Method) & $\begin{array}{c}\text { Initial Decant } \\
\text { (mg/kg } \\
\text { supernate) }\end{array}$ & $\begin{array}{c}\text { Decant A } \\
\text { (mg/kg } \\
\text { supernate) }\end{array}$ & $\begin{array}{c}\text { Decant B } \\
\text { (mg/kg } \\
\text { supernate) }\end{array}$ & $\begin{array}{c}\text { Decant C } \\
\text { (mg/kg } \\
\text { supernate) }\end{array}$ \\
\hline \multicolumn{5}{|l|}{ Replicate 1} \\
\hline $\mathrm{NO}_{2}^{-}(\mathrm{IC})$ & 43200 & 17200 & 6320 & 1010 \\
\hline $\mathrm{NO}_{3}^{-}(\mathrm{IC})$ & 61400 & 25700 & 8960 & 1430 \\
\hline $\mathrm{SO}_{4}^{2-}(\mathrm{IC})$ & 20600 & 7020 & 3010 & 423 \\
\hline $\mathrm{Na}$ (ICP-AES) & 136000 & 54000 & 20200 & 3150 \\
\hline S (ICP-AES) & 7060 & 2700 & 1090 & 183 \\
\hline Al (ICP-AES) & 11500 & 4590 & 1710 & 254 \\
\hline \multicolumn{5}{|l|}{ Replicate 2} \\
\hline $\mathrm{NO}_{2}^{-}$(IC) & 45100 & 16100 & 6190 & 825 \\
\hline $\mathrm{NO}_{3}^{-}(\mathrm{IC})$ & 63800 & 24000 & 8800 & 1160 \\
\hline $\mathrm{SO}_{4}^{2-}(\mathrm{IC})$ & 21300 & 6580 & 2920 & 330 \\
\hline $\mathrm{Na}$ (ICP-AES) & 138000 & 50700 & 20000 & 2550 \\
\hline S (ICP-AES) & 6990 & 2490 & 1060 & 152 \\
\hline $\mathrm{Al}$ (ICP-AES) & 11700 & 4380 & 1700 & 207 \\
\hline Density (g/mL) & 1.34 & 1.12 & 1.04 & 1.00 \\
\hline
\end{tabular}


The elemental results for the digestion of the slurry remaining after Decant $\mathrm{C}$ are given in Table 2-15. A mass balance on $\mathrm{Al}$ gives a result that is four times the measured result.

Table 2-15. Major Elements (>1,000 mg/kg) Detected by ICPAES in the Washed Decanted-Tank 51/Tank 4 Sludge Blend

\begin{tabular}{ccc}
\hline Species & $\begin{array}{c}\text { Replicate } \mathbf{1} \\
\text { (mg/kg slurry) }\end{array}$ & $\begin{array}{c}\text { Replicate } 2 \\
\text { (mg/kg slurry) }\end{array}$ \\
\hline $\mathrm{Al}$ & 7860 & 7700 \\
$\mathrm{Ca}$ & 2020 & 1950 \\
$\mathrm{Fe}$ & 46700 & 45300 \\
$\mathrm{Mn}$ & 11100 & 10800 \\
$\mathrm{Na}$ & 20700 & 20600 \\
$\mathrm{Ni}$ & 8580 & 8330 \\
$\mathrm{~S}$ & 1100 & 948 \\
$\mathrm{U}$ & 11200 & 10900 \\
\hline
\end{tabular}




\subsection{DISCUSSION}

\subsection{Sulfur}

The conversion of the total supernate sulfur values, as shown in Table 2-2, from molar to wt $\%$ of total solids, yields $3.28 \mathrm{wt} \% \mathrm{~S}$ for the Tank 4 sample. Comparing this value with the total slurry sulfur value in Table $2-4,3.68 \mathrm{wt} \% \mathrm{~S}$, indicates that $0.40 \mathrm{wt} \%$ of the total sulfur on a total dried solids basis is insoluble, or possibly better described as undissolved. By comparison, $0.127 \mathrm{wt} \%$ of total sulfur in the current SB5 material being processed in DWPF is "undissolved" that a major fraction of the sulfur had been found in the insoluble solids fraction of a DWPF sludge batch. The degree to which this "undissolved" sulfur would be removed during washing of SB6 in Tank 51 has been a matter of some concern. The scope of the original $\mathrm{TTR}^{2}$ for this work was expanded by the customer to help address questions about the impact of washing on total sulfur levels in SB6. This is discussed further in the washing discussion below.

When the Tank 4 supernate sulfur value by ICP-AES (Table 2-2) is put on a slurry sulfate basis, the result is $36,800 \mathrm{mg}$ sulfate $/ \mathrm{kg}$ slurry. This is higher than the sulfate value measured in the supernate by IC of $29,800 \mathrm{mg} / \mathrm{kg}$ slurry, indicating that some $19 \%$ of the soluble sulfur is present as a species other than sulfate and hence not detected by ion chromatography. Therefore total supernate sulfur by ICP-AES should be monitored during washing in addition to supernate sulfate in order to avoid under estimating the amount of sulfur species removed or remaining in the supernate.

\subsection{Elemental Ratios}

A comparison of the elemental ratios for the major insoluble solids species using data from Table 2-4 and References 1 and 10 is given in Table 3-1. These ratios should remain constant, with the exception of Al for these unwashed samples, unless an addition of material containing one or more elements of interest is made. The $\mathrm{Al} / \mathrm{Fe}$ ratio is misleading because a significant portion of the soluble $\mathrm{Al}$ in the unwashed, undecanted Tank 51-E1 sample will be removed. That aside, the $\mathrm{Ca} / \mathrm{Fe}$ and $\mathrm{U} / \mathrm{Fe}$ ratios for the Tank 4 and Tank 51-E1 components of SB6 are lower than the current ratios for these elements in SB5. The final $\mathrm{Mn} / \mathrm{Fe}$ ratio will depend on the relative contributions of Tank 4 and Tank 51 to the final SB6 composition, so at this time one cannot predict if the ratio will be higher or lower than in SB5.

Table 3-1. Comparison of Elemental Ratios for Major Elements in the Tank 4, Tank 51-E1, and Current SB5 Samples

\begin{tabular}{cccc}
\hline Element Ratio & $\begin{array}{c}\text { Tank 4 } \\
\text { (Unwashed) }\end{array}$ & $\begin{array}{c}\text { Tank 51 - E1 } \\
\text { (Unwashed) }\end{array}$ & $\begin{array}{c}\text { Tank 40 - SB5 } \\
\text { WAPS }^{\mathbf{1 0}}\end{array}$ \\
\hline $\mathrm{A} / \mathrm{Fe}$ & 0.36 & 4.8 & 0.60 \\
$\mathrm{Ca} / \mathrm{Fe}$ & 0.036 & 0.058 & 0.092 \\
$\mathrm{Mn} / \mathrm{Fe}$ & 0.050 & 0.47 & 0.23 \\
$\mathrm{U} / \mathrm{Fe}$ & 0.29 & 0.18 & 0.33 \\
\hline
\end{tabular}

1. Pickenheim, B. R., Bannochie, C. J., Pareizs, J. M., and Click, D. R. Results of the Analysis of Tank 51 E-1 Sample (HTF-51-09-74 \& -75) and Tank 12 Post-Aluminum Dissolution Rheology, SRNL-L3100-200900190, Savannah River Site, Aiken, SC 29808 (2009). 10. Bannochie, C. J., Click, D. R. Tank 40 Final SB5 Chemical Characterization Results Prior to Np Addition, SRNL-STI-2009-00060, Rev. 1, Savannah River Site, Aiken, SC 29808 (2009). 


\subsection{Noble Metal Ratios}

A comparison of the fission yield ratios for $\mathrm{Ru}: \mathrm{Rh}, \mathrm{Ru}: \mathrm{Pd}$, and $\mathrm{Ru}: \mathrm{Ag}$ with those measured for the Tank 4 sample is provided in Table 3-2. The Tank 51-E1 sample and Tank 40 SB5 WAPS sample results are also provided for comparison. The ratios are based upon $\mathrm{Ru}$ due to its relatively high concentration in the sludge as compared with the other noble metals. The $\mathrm{Ru}: \mathrm{Rh}$ ratio agrees reasonably well for all three samples, while the $\mathrm{Ru}: \mathrm{Ag}$ ratios differ significantly from the fission yield ratios. This lack of agreement for the Ag ratios is not unexpected since the majority of the $\mathrm{Ag}$ is natural $\mathrm{Ag}$ originating from $\mathrm{Ag}$ saddles used in the dissolvers to scavenge radioactive iodine, while the noble metals are fission products of U235. Consequently the relative concentration of $\mathrm{Ag}$ is not expected to be in proportion to the fission yields of its two isotopes. The Ru:Pd ratio for Tank 4 agrees reasonable well with that predicted by the fission yield, but it differs significantly for the unwashed Tank 51-E1 and current SB5 material. A possible explanation for this is that a portion of the $\mathrm{Pd}$ is soluble and hence has fractioned off into the salt waste, thus increasing the ratio of $\mathrm{Ru}$ to $\mathrm{Pd}$ in the sludge waste.

Table 3-2. Fission Yield Ratios and Measured Noble Metal Ratios for Tank 4, Tank 51-E1, and the SB5 WAPS Samples

\begin{tabular}{ccccc}
\hline Ratio & Fission Yield & Tank 4 & Tank 51 $-\mathbf{E 1}^{\mathbf{1}}$ & $\begin{array}{c}\text { Tank 40 - SB5 } \\
\text { WAPS }^{\mathbf{1 0}}\end{array}$ \\
\hline $\mathrm{Ru}: \mathrm{Rh}$ & 3.7 & 4.1 & 4.8 & 4.6 \\
$\mathrm{Ru}: \mathrm{Pd}$ & 6.9 & 8.1 & 21 & 29 \\
$\mathrm{Ru}: \mathrm{Ag}$ & 342 & 15 & 5.0 & 7.2 \\
\hline
\end{tabular}

1. Pickenheim, B. R., Bannochie, C. J., Pareizs, J. M., and Click, D. R. Results of the Analysis of Tank 51 E-1 Sample (HTF-5109-74 \& -75) and Tank 12 Post-Aluminum Dissolution Rheology, SRNL-L3100-2009-00190, Savannah River Site, Aiken, SC 29808 (2009).

10. Bannochie, C. J., Click, D. R. Tank 40 Final SB5 Chemical Characterization Results Prior to Np Addition, SRNL-STI2009-00060, Rev. 1, Savannah River Site, Aiken, SC 29808 (2009).

\subsection{Rheology Conclusions}

Three main conclusions can be drawn from the rheology results. First, the Tank 4 sample appears, at this level of insoluble solids concentration, to behave as a Newtonian liquid with no measurable yield stress as shown by the data reported in Table 2-7. Second, the decanted Tank 51-E1 material exhibited yield stress along with much higher viscosity than measured for Tank 4. And finally, the blend of Tank 4 and decanted Tank 51-E1 showed that a significant reduction in the rheological properties of the decanted Tank 51-E1 material can be gained by the addition of Tank 4 material.

\subsection{Settling Study Observations}

The settling curves shown previously in Figure 2-7 indicate that the settling behavior of the decanted Tank 51-E1 sample (Al dissolution treated HM sludge) is very slow and essentially stops after 10 days. The addition of Tank 4 material (PUREX sludge) significantly improves the settling behavior of the decanted Tank 51-E1 sludge. The blended material had rapid settling over the first five days, but continued to settle slowly even after 10 days.

\subsection{Modeling Observations}

The results of the OLI simulation calculations show that the presence of undissolved Burkeite in the Tank 4 sample is reasonable given the experimentally determined composition and assuming a small difference in the $\mathrm{Na}$ concentration that is well within the analytical uncertainty. 
The overall composition predictions from the OLI model match the measured values very closely. The major differences are:

1. The predicted undissolved $\mathrm{Al}$ is about $4 \mathrm{~mol} \%$ of the total $\mathrm{Al}$ compared to the measured 13 mol\%. The OLI software does not predict Al solubility well unless the actual form of the undissolved $\mathrm{Al}$ is known.

2. The predicted soluble phosphate is higher than measured.

3. About $3.5 \mathrm{~mol} \%$ of the carbonate was calculated to be associated with Burkeite whereas none was calculated for the sample analysis.

4. The Na content had to be increased from 5272 to $5379 \mathrm{mmol} / \mathrm{kg}(121205 \mathrm{mg} / \mathrm{kg}$ to 123650 $\mathrm{mg} / \mathrm{kg}$ ) to precipitate $\mathrm{S}$ as Burkeite. This increased value is $2 \%$ higher than the calculated charge balance value, which is well within the analytical uncertainty.

5. The predicted undissolved solids were slightly higher than measured. The actual hydration of the species after a total solids determination is not known so the correct choice of solid species in OLI cannot be made. Generally, the OLI predicted species contain more water of hydration than are probably present in the solids determination product.

\subsection{Sludge Washing}

The purpose of washing is to remove soluble species from sludge slurry, primarily Na. However, with the SRNL washing of the decanted Tank 51/Tank 4 blend, the primary purpose was to determine if currently insoluble sulfur would dissolve, and to determine the extent of sulfur removal during washing. Sulfur removal, along with the other primarily soluble species, Fe, and Al is presented as a mass balance in Table 3-3 below. The Al values shown in the table appear to be biased low based on those predicted values from the OLI model. They may in fact be biased low as a result of the aqua regia digestion and the observed presence of some undissolved white solids that in the past has been an Al species. 
Table 3-3. Mass Balance for Washing the Decanted-Tank 51/Tank 4 Sludge Blend

\begin{tabular}{|c|c|c|c|c|c|c|c|}
\hline & $\begin{array}{c}\text { Al } \\
\text { (mg) }\end{array}$ & $\begin{array}{l}\text { Soluble } \\
\text { Al (mg) }\end{array}$ & $\begin{array}{c}\text { Fe } \\
(\mathbf{m g})\end{array}$ & $\begin{array}{c}\mathrm{Na} \\
(\mathrm{mg})\end{array}$ & $\begin{array}{c}\mathrm{S} \\
(\mathrm{mg})\end{array}$ & $\begin{array}{l}\mathrm{NO}_{2}^{-} \\
\text {(mg) }\end{array}$ & $\begin{array}{l}\mathrm{NO}_{3}^{-} \\
\text {(mg) }\end{array}$ \\
\hline \multicolumn{8}{|l|}{ Replicate 1} \\
\hline Initial Amount $^{1}$ & 553 & 362 & 307 & 3901 & 182 & 1233 & 1658 \\
\hline Initial Decant Removed & -120 & -120 & ND & -1414 & -73 & -447 & -636 \\
\hline Decant A removed & -150 & -150 & ND & -1763 & -88 & -562 & -838 \\
\hline Decant B Removed & -46 & -46 & ND & -544 & -29 & -170 & -241 \\
\hline Decant C Removed & -6 & -6 & ND & -75 & -4 & -24 & -34 \\
\hline Calculated remaining & 231 & 40 & 307 & 105 & -12 & 30 & -91 \\
\hline Analyzed remaining $^{2}$ & $53^{4}$ & 1.3 & 318 & 141 & 7 & NM & NM \\
\hline Percent remaining ${ }^{3}$ & 10 & 0.4 & 100 & 4 & 4 & NA & NA \\
\hline \multicolumn{8}{|l|}{ Replicate 2} \\
\hline Initial Amount ${ }^{1}$ & 580 & 380 & 322 & 4092 & 191 & 1293 & 1739 \\
\hline Initial Decant Removed & -143 & -143 & ND & -1679 & -85 & -550 & -779 \\
\hline Decant A removed & -144 & -144 & ND & -1664 & -82 & -529 & -787 \\
\hline Decant B Removed & -47 & -47 & ND & -556 & -29 & -172 & -244 \\
\hline Decant C Removed & -5 & -5 & ND & -61 & -4 & -20 & -27 \\
\hline Calculated remaining & 241 & 41 & 322 & 133 & -9 & 22 & -98 \\
\hline Analyzed remaining ${ }^{2}$ & $56^{4}$ & 1.2 & 339 & 150 & 8 & NM & NM \\
\hline Percent remaining ${ }^{3}$ & 10 & 0.3 & 100 & 4 & 4 & NA & NA \\
\hline
\end{tabular}

${ }^{1}$ Based on a calculated composition of Tank 51/Tank 40 (see Table 2-13).

${ }^{2}$ Results based on ICP-AES analysis of slurry remaining after washing.

${ }^{3}$ Based on the initial amount and analyzed remaining.

${ }^{4}$ The aluminum result from the slurry digestion may be biased low. An aqua regia digestion was used which may not dissolve some Al species. $\mathrm{NA} \equiv$ Not Applicable

$\mathrm{ND} \equiv$ Not Detected

$\mathrm{NM} \equiv$ Not Measured

Presented in Table 3-4 is the cumulative percent of the soluble species and Al removed following each decant. As can be seen, following Decant B, greater than 100 percent of the $\mathrm{S}$ and nitrate is calculated to have been removed. This could be due to analytical uncertainties of the supernate analyses and uncertainties in the calculation of the initial amounts. Note that initial amounts were calculated by mass balance with inputs being the Tank 4 analyses and the Tank 51 analyses followed by adjustment for the decant prior to mixing with Tank 4. It should also be noted that the Tank 51/Tank 4 combination was made by volume and converted to mass using measured densities, another source of uncertainty. In the calculation of insoluble $\mathrm{S}$, the $\mathrm{wt} \%$ insoluble solids, a key input, was assumed, not measured Unfortunately, due to these uncertainties and assumptions, a definitive quantification of insoluble $\mathrm{S}$ is not possible. Based on the digestion results of the washed slurry, 96\% of the $\mathrm{S}$ was removed (see Table 3-5). This is equivalent to the percent of Na removed. Based on the washing data, greater than $100 \%$ of the $\mathrm{S}$ was removed, indicating that the initial S concentration could have been higher than calculated; however, the calculated $\mathrm{S}$ remaining is on the order of the measurement uncertainty. 
Table 3-4. Cumulative Component Percent Removed Following Each Decant

\begin{tabular}{lccccc}
\hline & Al & Na & S & $\mathbf{N O}_{2}{ }^{-}$ & $\mathbf{N O}_{3}{ }^{-}$ \\
\hline Replicate 1 & & & & & \\
Initial Decant & 21 & 36 & 41 & 36 & 39 \\
Decant A & 48 & 80 & 89 & 82 & 90 \\
Decant B & 57 & 94 & 106 & 96 & 105 \\
Decant C & 58 & 96 & 108 & 98 & 107 \\
& & & & & \\
Replicate 2 & & & & & \\
Initial Decant & 24 & 40 & 45 & 43 & 45 \\
Decant A & 49 & 80 & 88 & 83 & 91 \\
Decant B & 57 & 94 & 104 & 97 & 105 \\
Decant C & 58 & 95 & 106 & 98 & 107 \\
\hline
\end{tabular}

Based on the OLI modeling about $12 \%$, or $780 \mathrm{mg} / \mathrm{kg}$, of the $\mathrm{S}$ was initially insoluble. If $2 \%$ of the initially soluble $\mathrm{S}(5450 \mathrm{mg} / \mathrm{kg})$ remained $(\sim 110 \mathrm{mg} / \mathrm{kg})$ and $4 \%$ of the total S remained $(\sim 250 \mathrm{mg} / \mathrm{kg})$, then about $140 \mathrm{mg} / \mathrm{kg}$ of the initially insoluble $\mathrm{S}$ remained. This is about $18 \%$ of the initially insoluble $\mathrm{S}$, so based on the final washed sludge analysis for $\mathrm{S}, 78 \%$ of the initially insoluble $\mathrm{S}$ may have dissolved. If the washing data for $\mathrm{S}$ is used, the amount dissolved is $100 \%$. That $78-100 \%$ of the initially insoluble $\mathrm{S}$ dissolved supports the hypothesis that most of the initially insoluble $\mathrm{S}$ was Burkeite. From the amounts of $\mathrm{Ba}$ in the samples, and assuming $\mathrm{BaSO}_{4}$ is totally insoluble, $\mathrm{BaSO}_{4}$ accounts for about $2.2 \%$ of the initially insoluble S.

Analyzing this another way by comparing the analysis of Decant $\mathrm{C}$, which represents the soluble Na and $\mathrm{S}$ in the final decanted slurry, and that of the final digestion, which represents the total solids. If it is assumed that the final slurry is $20 \%$ insoluble solids, the Decant $C$ results can be placed on a slurry basis (1-weight fraction of insoluble solids = weight fraction of supernate). An estimate of the amount of insoluble $\mathrm{Na}$ and $\mathrm{S}$ can then be made by comparing the soluble amounts to the total amounts. The results of this exercise are given in Table 3-5. As can be seen, $90 \%$ of the detected $\mathrm{Na}$ and $\mathrm{S}$ are insoluble after the washing is performed, representing 3-4\% of the $\mathrm{Na}$ and $\mathrm{S}$ in the unwashed sludge. This insoluble $\mathrm{Na}$ and $\mathrm{S}$ would likely not be dissolved with normal washing. Converting the soluble $\mathrm{Na}$ and $\mathrm{S}$ values from Table 2-14 to a slurry basis and subtracting these from the final washed slurry values in Table 2-15, multiplying the result by the remaining slurry mass from Table 2-12, and finally dividing the result into the initial mass balance value shown in Table 3-3, one calculates the percent insoluble relative to initial shown below.. This exercise shows that $\mathrm{Na}$ and $\mathrm{S}$ behave similarly, and the majority of $\mathrm{S}$ (on the order of $95 \%$ in these tests) is either soluble or does dissolve during washing.

Table 3-5. Calculations of Insoluble Na and S in Washed Slurry with Comparison to Initial Amounts.

\begin{tabular}{lcc}
\hline \multicolumn{1}{c}{ Species } & $\begin{array}{c}\text { Replicate 1 } \\
\text { (mg/kg slurry) }\end{array}$ & $\begin{array}{c}\text { Replicate 2 } \\
\text { (mg/kg slurry) }\end{array}$ \\
\hline $\mathrm{Na}$ (soluble) & 2520 & 2040 \\
$\mathrm{Na}$ (total) & 20700 & 20600 \\
$\mathrm{~S}$ (soluble) & 146 & 122 \\
$\mathrm{~S}$ (total) & 1100 & 948 \\
\hline & (Percent) & (Percent) \\
$\mathrm{Na}$ (insoluble relative to initial) & 3 & 3 \\
$\mathrm{~S}$ (insoluble relative to initial) & 3 & 4 \\
\hline
\end{tabular}


SRNL-STI-2009-00544

Revision 0

This page intentionally left blank. 


\subsection{CONCLUSIONS}

The following conclusions were drawn from the Tank 4 analytical results reported here:

- Any projected blend of Tank 4 and the current Tank 51 contents will produce a SB6 composition that is lower in $\mathrm{Ca}$ and $\mathrm{U}$ than the current SB5 composition being processed by DWPF.

- Unwashed Tank 4 has a relatively large initial $\mathrm{S}$ concentration of $3.68 \mathrm{wt} \%$ on a total solids basis, and approximately $10 \%$ of the total $\mathrm{S}$ is present as an insoluble or undissolved form.

- There is $19 \%$ more $\mathrm{S}$ than can be accounted for by IC sulfate measurement. This additional soluble $\mathrm{S}$ is detected by ICP-AES analysis of the supernate.

- Total supernate and slurry sulfur by ICP-AES should be monitored during washing in addition to supernate sulfate in order to avoid under estimating the amount of sulfur species removed or remaining in the supernate.

- OLI simulation calculations show that the presence of undissolved Burkeite in the Tank 4 sample is reasonable, assuming a small difference in the $\mathrm{Na}$ concentration that is well within the analytical uncertainties of the reported value.

The following conclusions were drawn from the blend studies of Tank 4 and decanted Tank 51-E1:

- The addition of Tank 4 slurry to a decanted Tank 51-E1 sample significantly improved the degree and time for settling.

- The addition of Tank 4 slurry to a decanted Tank 51-E1 sample significantly improved the plastic viscosity and yield stress.

- The SRNL washing test, where nearly all of the wash solution was decanted from the solids, indicates that approximately $96 \%$ or more of the total $\mathrm{S}$ was removed from the blend in these tests, and the removal of the sulfur tracks closely with that of $\mathrm{Na}$. Insoluble (undissolved) $\mathrm{S}$ remaining in the washed sludge was calculated from an estimate of the final slurry liquid fraction, the $S$ result in the slurry digestion, and the $S$ in the final decant (which was very close to the method detection limit). Based on this calculated result, about $4 \%$ of the initial total $\mathrm{S}$ remained after these washes; this amount is equivalent to about $18 \%$ of the initially undissolved S. 
SRNL-STI-2009-00544

Revision 0

This page intentionally left blank. 


\subsection{REFERENCES}

1 Pickenheim, B. R., Bannochie, C. J., Pareizs, J. M., and Click, D. R. Results of the Analysis of Tank 51 E-1 Sample (HTF-51-09-74 \& -75) and Tank 12 Post-Aluminum Dissolution Rheology, SRNL-L31002009-00190, Savannah River Site, Aiken, SC 29808 (2009).

2 Martin, K. B. Tank 4F Characterization in Support of Bulk Waste Removal and Sludge Batch Preparation, HLE-TTR-2009-103, Rev. 0, Savannah River Site, Aiken, SC 29808 (2009).

${ }^{3}$ Bannochie, C. J., Pareizs, J. M. Qualification of DWPF Sludge Batch 6 and Characterization of Tank 4 Samples in the SRNL Shielded Cells: Task Technical and Quality Assurance Plan, SRNL-RP-200900473, Rev. 0, Savannah River Site, Aiken, SC 29808 (2009).

${ }^{4}$ Bannochie, C. J., Pareizs, J. M. Qualification of DWPF Sludge Batch 6 and Characterization of Tank 4 in the SRNL Shielded Cells: Analytical Study Plan, SRNL-RP-2009-00474, Rev. 0, Savannah River Site, Aiken, SC 29808 (2009).

${ }^{5}$ Coleman, C. J. Aqua Regia Dissolution of Sludge for Elemental Analysis, Manual L16.1, Procedure ADS-2226, Rev. 7, Savannah River Site, Aiken, SC 29808 (2008).

${ }^{6}$ Coleman, C. J. Alkali Fusion Dissolutions of Sludge and Glass for Elemental and Anion Analysis, Manual L16.1, ADS-2502, Rev. 6, Savannah River Site, Aiken, SC 29808 (2008).

${ }^{7}$ Smith, G. L. Characterization of Analytical Reference Glass - 1 (ARG-1), PNL-8992, Pacific Northwest (National) Laboratory, Richland, WA (1993).

${ }^{8}$ Marek, J. C., Correction Factor for Soluble and Insoluble Solids, SRTC-PTD-92-0040, Savannah River Site, Aiken, SC 29808 (1992).

${ }^{9}$ Darby, R., Chemical Engineering Fluid Mechanics, 2nd edition. Marcel Dekker: 2001.

${ }^{10}$ Bannochie, C. J., Click, D. R. Tank 40 Final SB5 Chemical Characterization Results Prior to Np Addition, SRNL-STI-2009-00060, Rev. 1, Savannah River Site, Aiken, SC 29808 (2009). 
SRNL-STI-2009-00544

Revision 0

This page intentionally left blank. 


\subsection{ACKNOWLEDGEMENTS}

The authors would like to acknowledge the support of the SRNL Shielded Cells technicians and supervision, and the responsiveness of the $\mathrm{AD}$ analysts to the short turn around times for sample analyses needed to support this work. 


\section{Distribution:}

S. L. Marra, 773-A

A. B. Barnes, 999-W

D. A. Crowley, 773-43A

S. D. Fink, 773-A

C. W. Gardner, 773-A

B. J. Giddings, 786-5A

C. C. Herman, 999-W

F. M. Pennebaker, 773-42A

J. P. Vaughan, 773-41A

D. K. Peeler, 999-W

M. E. Stone, 999-W

N. E. Bibler, 773-A

J. M. Pareizs, 773-A

D. C. Koopman, 999-W

J. R. Zamecnik, 999-W

S. H. Reboul, 773-A

D. R. Click, 773-A

D. C. Bumgardner, $704-56 \mathrm{H}$

M. T. Keefer, 241-156H

M. D. Buxton, 241-156H

H. B. Shah, 766-H

J. M. Gillam, 766-H

B. A. Hamm, 766-H

D. D. Larsen, 766-H

R. C. Jolly, 704-70F

A. J. Tisler, 704-26F

K. B. Martin, 704-71F

J. E. Occhipinti, 704-S

J. W. Ray, 704-S

R. N. Hinds, 704-S

J. F. Iaukea, 704-30S

M. A. Broome, 704-29S

R. T. McNew, 704-27S

A. R. Shafer, 704-27S

M. C. Clark, 704-27S

J. M. Bricker, 704-27S

T. L. Fellinger, 704-26S

H. H. Elder, 704-24S 